\title{
THE EXPANSION OF MASS EDUCATION IN TWENTIETH CENTURY LATIN AMERICA: A GLOBAL COMPARATIVE PERSPECTIVE *
}

\author{
EWOUT FRANKEMA \\ Utrecht University $^{\text {a }}$
}

\begin{abstract}
This paper studies the expansion of mass education in Latin America in the twentieth century from a global comparative perspective. The paper argues that expansion in terms of enrolment and attainment levels was quite impressive. A comparative analysis of the grade enrolment distribution demonstrates, however, that the rapid expansion of primary school enrolment did not correspond with an equally impressive improvement in educational quality. The persistently large tertiary education bias in public education spending suggests that part of the poor quality performance is related to a lack of fiscal support for primary education and that the political economy explanation for educational underdevelopment, as advanced by Engerman, Mariscal and Sokoloff for the $19^{\text {th }}$ century, still applied to Latin America during most of the $20^{\text {th }}$ century.
\end{abstract}

Keywords: education, Latin America, grade distribution, public spending

JEL Classification: I20, I22, I28, O10, O54, P48

* Received 06/02/2009. Accepted 08/21/2009. The author wishes to thank Jan Pieter Smits, Bart van Ark, Jutta Bolt, Alan Taylor, Peter Lindert, Henry Willebald, Luis Bértola and three anonymous referees for their valuable comments on previous drafts. Financial support from the Dutch Science Foundation (NWO) and ESF (Global Euronet) is gratefully acknowledge.

a Faculty of Humanities, Drift 10, 3512 BS, Utrecht, The Netherlands, e.frankema@uu.nl. 


\section{RESUMEN}

Este artículo estudia la expansión de la enseñanza básica en América Latina durante el siglo xx desde una perspectiva mundial y comparativa. El trabajo argumenta que los niveles y la expansión, en términos de matrícula, fue bastante notable. Sin embargo, el análisis comparativo del grado de distribución de la matrícula demuestra que dicha expansión no se corresponde con mejoras equivalentes en la calidad de la educación. El persistente sesgo del gasto público en educación terciaria sugiere que la explicación de su baja calidad está relacionada con las carencias del financiamiento público de la educación primaria. Esto implica que la tesis de economía política sobre el subdesarrollo educativo de América Latina que proponen Engerman, Mariscal y Sokoloff para el siglo XIX, se mantiene durante la mayor parte del siglo XX.

Palabras clave: educación, América Latina, distribución de la matrícula, gasto público

\section{INTRODUCTION}

Driven by the spirit of revolution, education for the masses became an important issue on the political agenda of Latin America's independence fighters in the early $19^{\text {th }}$ century. San Martin, the liberator of Peru, decreed in 1822 that "Public instruction is the primary need of all peoples. Any government that does not promote it is guilty of a crime which later generations have the right to avenge, while cursing its memory " ${ }^{1}$. That other famous liberator, Simon Bolivar, ordered the establishment of a teacher training school in every departmental capital of Peru in 1825. He saw public schooling as a vital instrument for the promotion of social, cultural and economic development of the independent Latin American nation states and, to that end, stated that primary education had to be compulsory, secular and free of charge ${ }^{2}$. Yet, as conservative post-revolutionary regimes rose to power, the momentum for broad-based educational expansion disappeared as rapidly as it had emerged. In fact, there had never been a real sense of urgency among the ruling elites, which were traditionally dominated by the wealthy class of latifundistas.

In the stratified rural societies of early post-colonial Latin America the labour force still predominantly consisted of subsistence farmers, peones, debt-bonded serfs and slaves. Financing mass education would not only require redistributive taxes in favour of these groups, it could also lead to a

\footnotetext{
1 UNESCO (1958, pp. 836-837).
}

2 UNESCO (1958, pp. 836-837). 
growing demand for a political voice undermining the monopolies, privileges and interests of those in power. Engerman, Mariscal and Sokoloff have argued that high levels of economic, political and social inequality in Latin America have hampered the dissolution of the colonial political economic status quo to a much larger extent than in North America ${ }^{3}$. Prevailing aristocratic ideologies justified the idea that education was a privilege of the rich: poverty was believed to be a result of a lack of innate capacities and the introduction of expensive programs of mass education would be a waste of money ${ }^{4}$.

Besides, endemic political instability and chronic budget deficits impeded public investment in education and complicated the formation of an efficient bureaucratic apparatus to initiate and monitor the process of educational expansion. Meagre perspectives of social mobility and substantial private contributions (school fees) reduced the perceivable benefits of schooling among the poor. The Catholic Church resisted secular mass education, as it feared losing its monopoly on a beloved medium to instil religious authority. Hence, education remained a privilege for the elite and the popular demand for education only grew slowly ${ }^{5}$. Thus, at the close of the $19^{\text {th }}$ century, the British colonies Jamaica and Trinidad and Tobago recorded higher primary school enrolment rates than any of the independent Latin American nation states (see Table A.1 further below).

During the last quarter of the $19^{\text {th }}$ century a decisive move towards mass education took place in some of the more prosperous Latin American countries (LACs henceforth) such as Argentina, Chile and Costa Rica. In virtually all LACs primary schooling had become a common good by the end of the $20^{\text {th }}$ century. A large number of statistical reports demonstrate a dramatic increase in public educational investment and attainment levels through the $20^{\text {th }}$ century. Literacy rates increased exponentially. Especially during the middle decades of the century, educational expansion became part of encompassing social programs aimed at improving overall the living standards of Latin American people ${ }^{6}$. Significantly, the expansion of primary school enrolment rates accompanied a comparatively egalitarian gender distribution from the late $19^{\text {th }}$ century onwards ${ }^{7}$.

3 The political economy arguments are posited by many scholars. For Latin America especially by Sokoloff and Engerman (2000); Engerman, Haber and Sokoloff (2001) and Mariscal and Sokoloff (2000), but one may also refer to recent work by Lindert (2004, pp. 87-127) and (2009) and Wegenast (2009a) and (2009b).

4 Bakewell (2004: pp. 454-456).

5 This point has been made by numerous scholars. See for the general argument for instance Brock (1985); See specifically for Argentina Spalding (1972) or Parrado (1998); For Mexico Vaughan (1975) or for Chile Yeager (1991).

6 Astorga, Berges and Fitzgerald (2005).

7 Frankema (2009, pp. 93-97). 
Nevertheless, the literature interprets Latin American educational "progress» in different ways. Some scholars argue that the unequal distribution of education has constrained Latin American economic growth and, more generally, can be seen as an important determinant of high income inequality. Other studies deny such a relationship, since they do not find any evidence for educational retardation in Latin America from a comparative perspective ${ }^{8}$. This paper adopts a clear position, arguing that the rapid expansion of mass education in the region corresponded with poor educational quality improvements in a large majority of LACs.

To start with, it is shown that the rise in primary school enrolment rates in Latin America was neither slower nor faster than could be expected on the basis of the patterns observed in the rest of the world. It rose considerably faster than in most of today's OECD countries, yet notably more slowly than in the poorest developing countries in Sub Saharan Africa. Subsequently, it is argued that historical school enrolment rates only make sense in combination with grade enrolment and school completion data. A comparative analysis of the grade enrolment distribution reveals that it took even the most advanced LACs, such as Argentina, Chile and Uruguay, at least four decades to achieve acceptable levels of grade promotion and school completion after having achieved full primary school enrolment rates. Latin America performed worse than any other world region in this respect. Only in the 1980s did LACs start to amend the shortcomings of their primary education systems: grade repetition and precompletion drop out rates were reduced faster than in other developing regions. Finally, it is argued that the poor quality performance did not primarily result from a lack of public resources as such, but rather from a strong bias in public spending in favour of tertiary education (at the expense of primary education) suggesting that the political economy explanation for educational underdevelopment, as advanced by Engerman, Mariscal and Sokoloff for the $19^{\text {th }}$ century, still applied to Latin America during the $20^{\text {th }}$ century.

Section 2 introduces the different views on the comparative record of educational «development» in $20^{\text {th }}$ century Latin America and section 3 analyses the long run comparative development of primary school enrolment rates in the period 1870-2000. Section 4 presents a global comparative analysis of grade promotion and primary school completion using a grade enrolment distribution approach. Section 5 discusses the distribution of public educational spending. A conclusion is presented in section 6.

\footnotetext{
8 This refers to literature that will be discussed in section 2 .
} 


\section{DIFFERENT VIEWS ON THE COMPARATIVE DEVELOPMENT OF EDUCATION IN LATIN AMERICA}

The most widely held view in academic literature is that $20^{\text {th }}$ century educational development in Latin America was comparatively backward and its distribution comparatively unequal. Systematic quantitative analyses of primary, secondary and tertiary school enrolment expansion, school completion rates, the standard deviation of years of schooling attained, and various measures of educational expenditure reveal, among other things, a bias in public investment towards higher education combined with relatively poor primary school completion rates. In various studies Birdsall and others show that LACs have seriously lagged behind East Asian countries. The poor quality and unequal distribution of education in Latin America, so it is argued, explain part of the region's modest labour productivity growth and persistently high levels of income inequality ${ }^{9}$. Birdsall, Ross and Sabot (1997: p. 125) conclude that,

«The unequal distribution of education in Latin America, in terms of both quantity and quality, constrained economic growth in the region by resulting in forgone opportunities to increase labor productivity and change household behaviour. At the same time, the relatively small size of the educated labor force and the resulting high scarcity rents commanded by educated workers contributed to high inequality in the distribution of income».

Morley (2001: pp. 123-128, 140-148) underlines this view arguing that relative wage levels of university graduates are still higher in LACs than in other parts of the world, despite the rapid increase in, and supply of, university graduates since the 1970s. A recent report of Euromonitor International (2007: pp. 102-107) comparing income distribution across countries lists the ratio of average disposable income of people who completed tertiary education to the average net disposable income per capita. Appendix Figure 1 presents these figures in a scatter diagram, comparing LACs to the rest of the world. The estimated linear functions in the figure (intercept of the equation set at zero) leave little doubt. The average «tertiary education income premium» in Latin America of 251 per cent is only exceeded by three non-Latin American countries, i.e. Egypt (251.5 per cent), Jordan (260 per cent) and Saudi Arabia (278 per cent). The world average is 164 per cent. Indeed, these figures suggest a direct link between educational inequality and income inequality in present-days LACs.

9 See for instance Birdsall and Sabot (1994); Birdsall, Ross and Sabot (1997); Birdsall (1999); Park, Ross and Sabot (1996); Bourguignon (1993). 
However, other scholars find that the comparative levels of educational inequality in Latin America are modest and that the observable association between educational inequality and income inequality in Latin America is fairly weak ${ }^{10}$. These studies have something in common: they use the Barro and Lee dataset of educational attainment of the working age population to calculate Gini-coefficients of the attainment distribution ${ }^{11}$. The Gini, so it is argued, is a more comprehensive inequality indicator than such 'partial' indicators as school enrolment rates, completion rates or education expenditures per level of education. The World Bank report Inequality in Latin America, Breaking with History? (2004: p. 153) concludes, on the basis of the estimated relationship between educational Gini's and income Gini's, that,

"Latin American countries appear to have "too much" income inequality, given their levels of inequality in years of schooling [...] However, before jumping to the conclusion that educational disparities are definitely not the reason for high income inequality in Latin America, it should be pointed out that the years of schooling is a very imperfect measure of the human capital stock embodied in a person».

This finding is important for two reasons. First, the educational Gini apparently leads to other inferences than the broader set of indicators used by other studies. Frankema (2008a: pp. 439; 2008b: pp. 92-94) demonstrates that different inequality indicators indeed produce very different views on the extent of educational inequality and, for various reasons, disapproves of the use of the education Gini. Second, it leaves room for the possibility that educational inequality resides mainly in quality differences rather than in differences in years of schooling attained. This view has recently been empirically substantiated in a couple of papers by Hanushek and Woesmann (2009a; 2009b). Cole et al. (2004) use educational attainment data from the Barro and Lee database for a more unconventional argument: a lack of catching up growth in Latin America can definitely not be explained by slow educational development. The authors argue that several LACs such as Argentina, Chile and Uruguay obtained equal or even considerably higher attainment levels in the 1990s than many of the East Asian and European development successes such as Singapore, Portugal or Spain. Hence, Cole et al. argue that,

10 See for comparative analyses of educational inequality for instance Ram (1990); Lopez, Thomas and Wang (1998); Hanushek and Kimko (2000); Castello and Domenech (2002); Gregorio and Lee (2002); Thomas, Wang and Fan (2001); Sahn and Younger (2004).

11 Barro and Lee (1993) and (2001). 
«We conclude that human capital is not the major factor in explaining Latin America's TFP gap, nor does it appear to play an important role in Latin America's long run stagnation» ${ }^{12}$.

Indeed, a closer look at the educational attainment record of most LACs does reveal major progress in educational development during the second half of the $20^{\text {th }}$ century. In a long run comparative survey of literacy and educational attainment Berges (2009: p. 21) points out, however, that the transition from primary to secondary education was deterred. This is in line with the argument presented in section 4 that attainment data (which are basically enrolment data converted with a perpetual inventory method) are missing an important part of the picture: enrolment rates only provide information on the actual number and percentage share of children in a pre-specified age group who are «officially registered» as being enrolled. Whether they attend school on a regular basis is not known. In section 4 it will be argued that this distinction between registered enrolment and actual attendance is crucial for the assessment of mass education expansion in $20^{\text {th }}$ century Latin America.

\section{THE EXPANSION OF PRIMARY EDUCATION IN LATIN AMERICA, $1870-2000$}

Gross primary school enrolment rates in twenty LACs during the period 1870-2000 are presented in Table 1. The figures refer to the ratio of enrolled children aged 5-14 over the country specific primary school age group. The pre-war estimates are retrieved from Lindert (2004) and Mitchell (2007) and the post-war figures are from the UNESCO Statistical Yearbooks (see sources below table). Table 1 shows that in the year 2000 all LACs reported gross primary school enrolment rates above 100 per cent, except Haiti ${ }^{13}$. The table also shows that the acceleration in the spread of education in the majority of LACs took place in the course of the $20^{\text {th }}$ century and that the intra-regional dispersion in primary school enrolment rates was large until the 1970s at least. When concentrating on the timing of the transition towards mass education we can roughly distinguish three groups of LACs. In the last three decades of the $19^{\text {th }}$ century the expansion of primary schooling is most notable in Argentina, Chile, Costa Rica and Uruguay ${ }^{14}$. The British colonies Jamaica and Trinidad \& Tobago recorded

12 Cole, Ohanian, Riascos and Schmitz (2004, p. 14).

13 Haiti recently stopped reporting school enrolment data altogether. Contrary to net enrolment rates, gross enrolment rates may surpass 100 per cent since they are calculated as the ratio of the total number of children enrolled over the number of children in the specific school age group.

14 Since a lot of observations for the period 1870-1900 are missing we have to be cautious: a backward extrapolation of the reported figures, as well as qualitative historical sources, suggest 


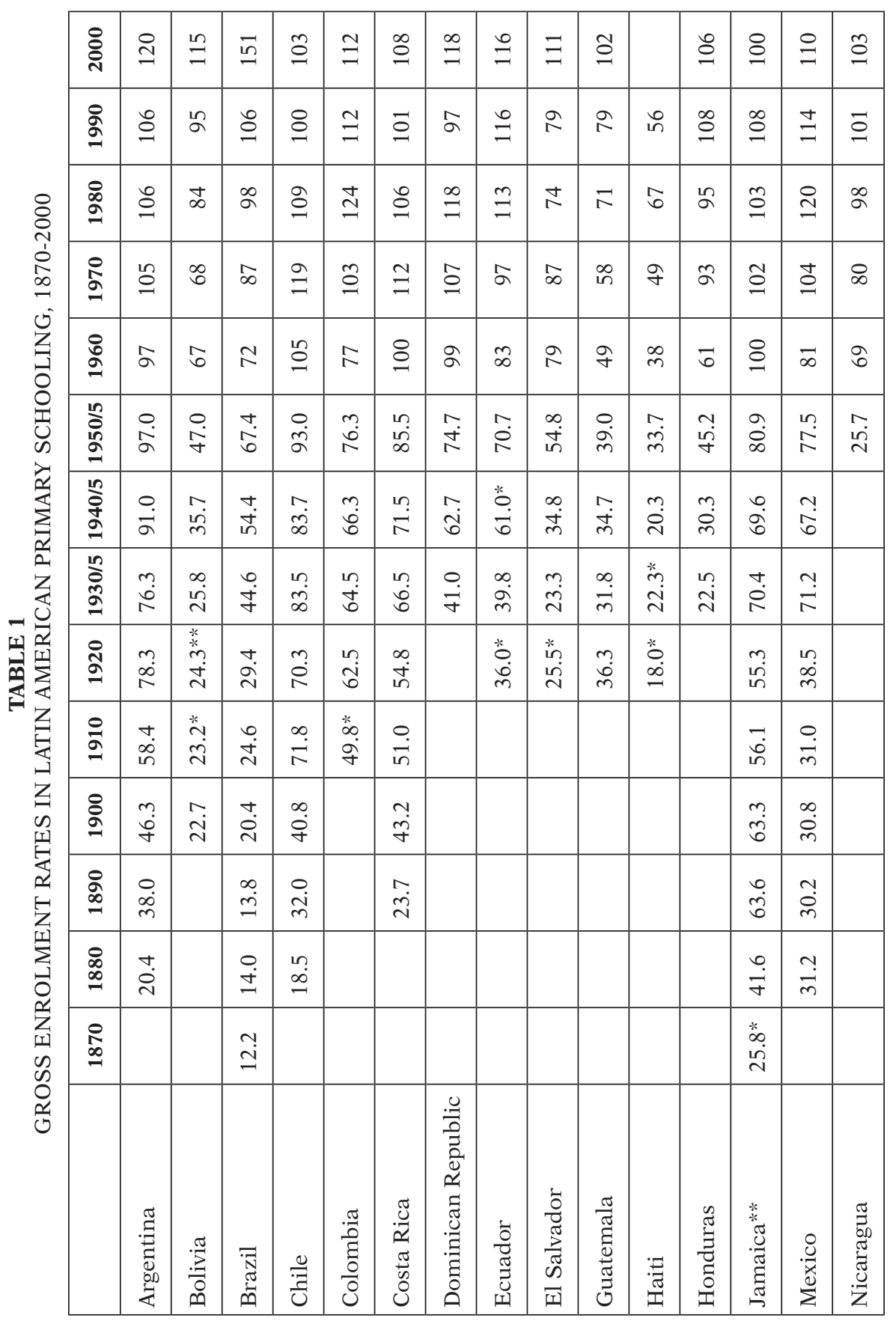




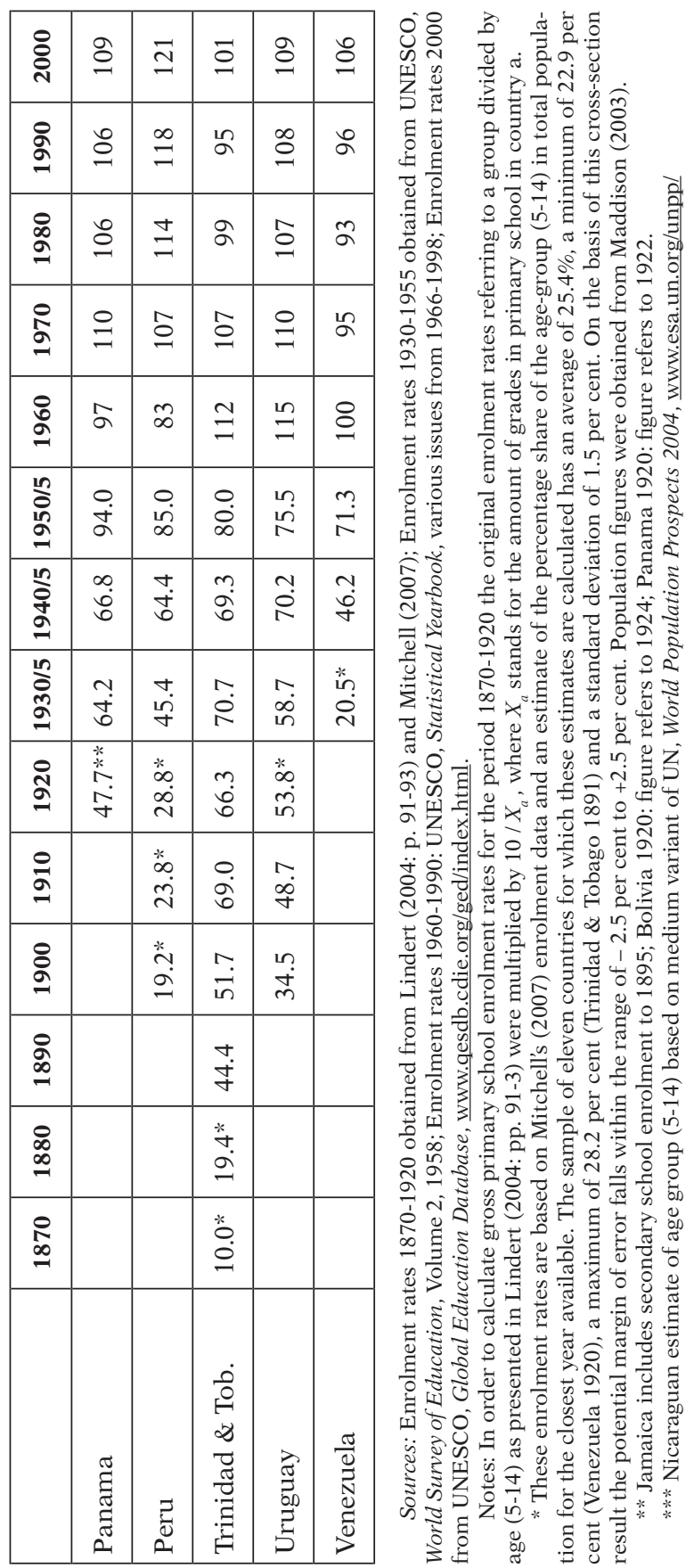


the fastest rise and were the only two countries recording a rate of over 50 per cent around 1900. After gaining independence from Colombia in 1903, Panama joined the club of «early movers». During the 1920s and 1930s the rise in gross enrolment rates started to accelerate in Bolivia, the Dominican Republic, Ecuador, El Salvador, Mexico, Brazil, Peru and Venezuela. Some of the poorest countries in the region, such as Guatemala, Honduras, Nicaragua and Haiti, were typically "late movers», where the acceleration in educational expansion only occurred in the early post-war decades.

This threefold classification seems to reflect some important features of Latin America's historical legacy. The "early movers» constitute the countries in the former colonial periphery where the impact of Iberian metropolitan policies had been markedly smaller than in the core areas such as New Spain and Peru. These countries further appear to have been $a$ ) the most urbanised (Argentina, Uruguay), b) the most ethnically homogenous, including large shares of European immigrant population (Argentina, Uruguay), c) comparatively less unequal rural societies (Argentina, Uruguay, Costa Rica) and, d) of British colonial origin (Jamaica and Trinidad and Tobago). The "late movers» are typically the most stratified and least urbanised rural societies characterised by large ethnic heterogeneity and a relatively small Creole elite. Yet, the majority of LACs fell in between these extremes and started to invest in mass education in the early $20^{\text {th }}$ century, especially during the 1920 s and 1930s.

Engerman, Mariscal and Sokoloff have argued forcibly that educational development in Latin America was lagging from a comparative perspective, but is it possible that LACs were simply too poor to start expanding public education? ${ }^{15}$ Figure 1 plots the available Latin American gross enrolment rates between 1870 and 1930 against Maddison's GDP per capita estimates and compares these to a benchmark group of industrialising countries ${ }^{16}$. A non-linear trend line is added to compare the correlation between enrolment rates and GDP in both samples. Although this is a very crude analysis, especially given the doubtful quality of Latin American GDP figures for this period, there still seems to be a clear pattern: when controlling for GDP per capita levels, the LACs had substantially lower enrolment rates than could be expected. Of course there was some intra-regional variation. Costa Rica and Mexico in 1930 are relatively close to the trend line of the control group, while Argentina and Chile exceed the Latin American trend line throughout the period 1870-1930. Brazil, Guatemala, Peru and Uruguay on the other

\footnotetext{
that the transition towards mass education took place somewhere between 1870 and 1900. Literacy rates recorded in the late $19^{\text {th }}$ and early $20^{\text {th }}$ century also support the idea that these countries were ahead of the rest of the region. See for instance Thorp (1998, p. 354); Mariscal and Sokoloff (2000, pp. 172-173).

${ }^{15}$ See Sokoloff and Engerman (2000); Mariscal and Sokoloff (2000).

16 Maddison (2003).
} 
hand are constantly below the Latin American trend line. Yet, from an aggregate point of view, it is clearly shown that LACs were «too rich» for their comparative rates of enrolment, at least up to 1930.

FIGURE 1

GDP PER CAPITA ( $X$-AXIS) VERSUS PRIMARY SCHOOL ENROLMENT RATES ( $Y$-AXIS), LATIN AMERICA VERSUS A SELECTION OF EUROPEAN COUNTRIES, NEW WORLD COUNTRIES AND JAPAN, 1870-1930 (1990 US \$; AGE 5-14)

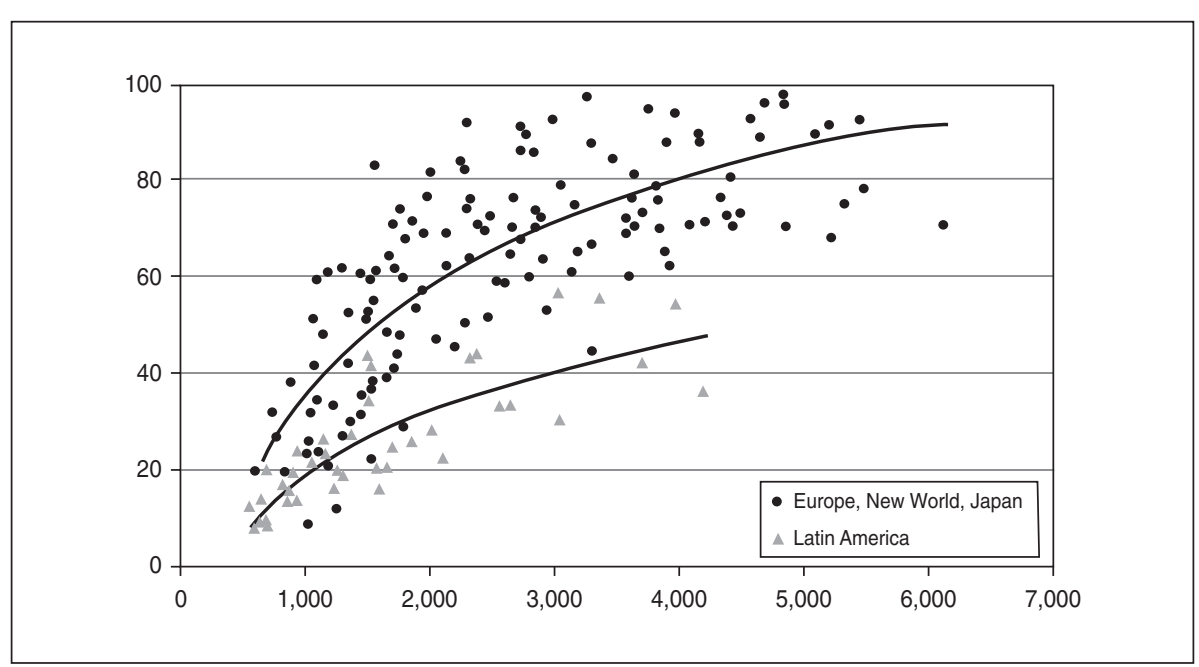

Sources: Maddison (2003) for GDP per capita estimates; Lindert (2004: pp. 91-93) and own calculations based on Mitchell (2007) for gross primary school enrolment rates. See also source description of table 1 .

Notes: Latin American countries included: Argentina, Brazil, Chile, Colombia, Costa Rica, El Salvador, Guatemala, Mexico, Peru, Uruguay; Countries included in the benchmark group: Austria, Belgium, Canada, Denmark, Finland, France, Greece, Hungary, Italy, Japan, Netherlands, New Zealand, Norway, Portugal, Romania, Spain, Sweden, Switzerland, UK, USA.

There are of course different ways of interpreting this finding. One possibility is that Latin American countries were extremely efficient in generating output from low levels of educational input. Such high input-output rates are, however, hard to square with the historical picture ${ }^{17}$. Much more con-

17 The World Survey of Education of the 1950s (UNESCO 1958) and an ECLAC report one decade later (ECLAC 1968) sum up a long list of problems encountered in the expansion of primary education in various LACs. Among these are 1) a lack of public financial resources, 2) a lack of well educated teachers, 3) geographical barriers hampering the establishment of schools and school attendance in isolated rural areas, 4) the language barrier in countries with large indigenous populations, 5) the indifference towards primary education on behalf of poor and low educated parents, 6) the practice of child labour provoking irregular school attendance, 7) insuf- 
vincing is the argument that Latin American countries followed a trajectory of natural resource induced growth, which produced comparatively high levels of income and growth during the era of export-led growth between 1870 and $1930{ }^{18}$. Natural resource abundance may have affected the political choice for educational investment in more than one way. First, as natural resource revenues produced favourable growth rates, they may have reduced the perceived importance of human capital accumulation for achieving long run sustainable welfare objectives. Second, high levels of inequality in income, assets and wealth is often one of the key features of resource-based economies and this negatively impacted on the overall level of public investment in schooling because of the political bias against redistribution produced by the influential wealth-owning elite ${ }^{19}$. The globalization literature has indicated that levels of income inequality were indeed increasing during the first wave of globalization up until the First World War ${ }^{20}$. So it seems that LACs failed to invest heavily in education at a time when resources for that purpose became increasingly available, without immediately confronting the negative income implications of such underinvestment ${ }^{21}$.

The literature thus suggests that the «delayed» transition towards mass education in Latin America is connected to the region's specific colonial heritage of inequality. A different question is whether the expansion of mass education, once underway, was any slower or faster compared to the standards observed in other countries or regions. Were the "early movers» in Latin America any slower or faster than their neighbours arriving even later on the scene? Michael Clemens has shown that present-day developing countries expand school enrolment rates at a much faster pace than the early industrialising countries back in the $19^{\text {th }}$ century ${ }^{22}$. He issued the warning that expanding enrolment too fast may have a cost in terms of quality maintenance.

Figure 2 presents the average annual increase of gross primary enrolment rates in a sample of LACs and non-LACs from 1830 to 2000. The underlying data are presented in Appendix Table A.1. The «average rate of expansion» is measured as the annual increase of the gross primary enrolment

ficient monitoring agencies to detect poor quality and enforce compulsory attendance. Given these circumstances it is hard to believe that educational output in terms of enrolment has been extremely efficient.

18 It would require too much space to give a comprehensive account of the literature on exportled growth in Latin America but Cárdenas, Ocampo and Thorp (2000) provide a nice overview.

19 Tim Wegenast's recent study is one of the rare attempts to establish a direct empirical link between asset inequality and educational performance, see Wegenast (2009a) and (2009b); for a more general empirical study on the relationship between natural resource abundance and income economic inequality see Spilimbergo, Londoño and Székely (1999).

20 Williamson (1999) and (2002). (2008).

21 For empirical support of this argument see Bértola, Camou, Maubrigades and Melgar

22 Clemens (2004). 
FIGURE 2

AVERAGE AND MAXIMUM ANNUAL INCREASE IN GROSS PRIMARY SCHOOL ENROLMENT RATES IN PERCENTAGE POINTS, LATIN AMERICA VERSUS A SAMPLE OF OECD COUNTRIES AND ASIAN AND AFRICAN COUNTRIES, $1830-2000$

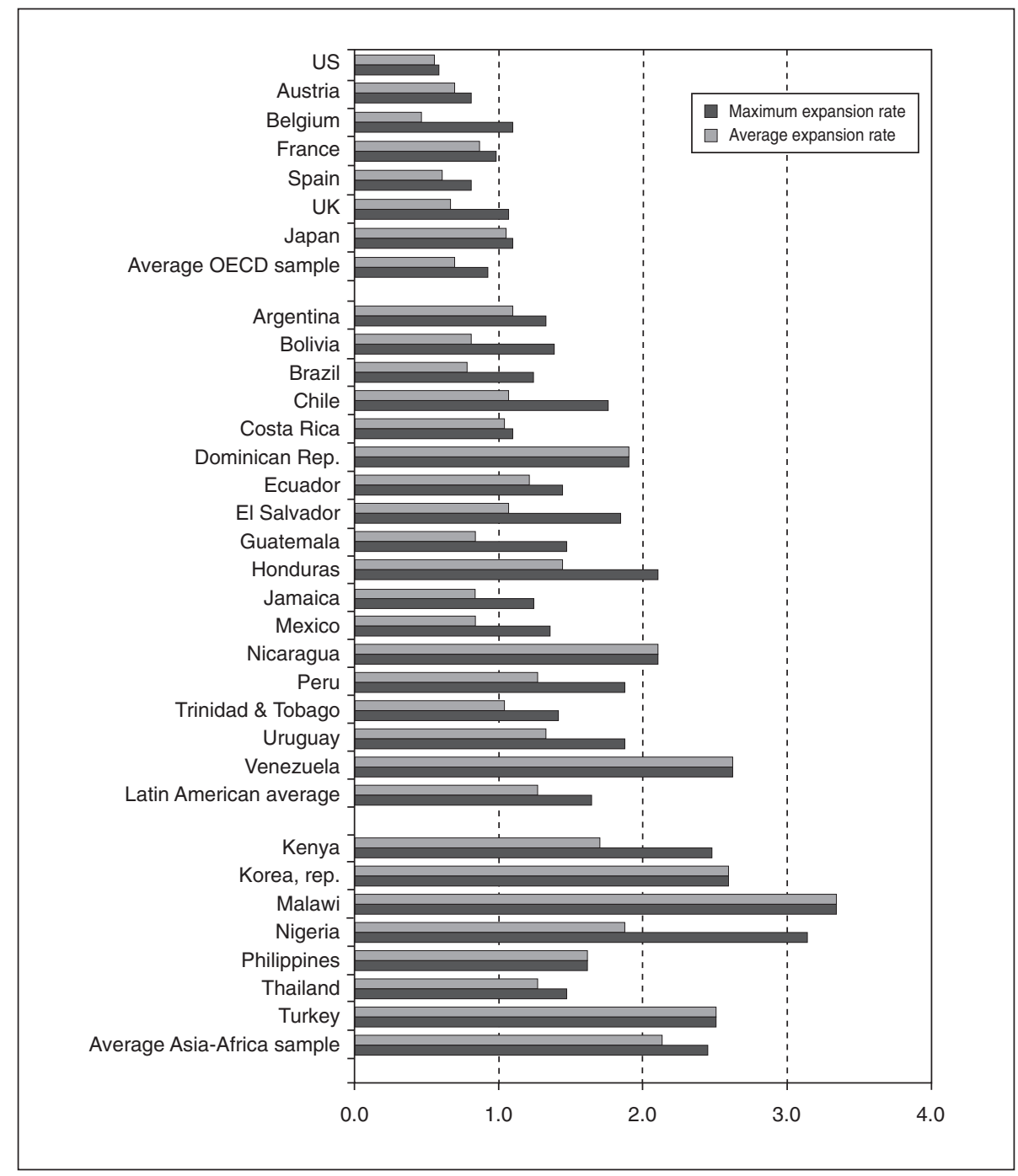

Sources: Author's own calculations. See Table 1 for the underlying data. 
rate between the first observable decade until the decade of full gross primary school enrolment. The «maximum rate of expansion» is measured as the average annual increase of the enrolment rate in the three consecutive decades with the largest expansion observed ${ }^{23}$.

Figure 2 underlines the argument of Michael Clemens that the pace of enrolment expansion in almost all LACs was faster than that of the "early movers» in the industrialising world. Interestingly, the pace of expansion was notably slower in most LACs than in some of the poorest parts of the developing world, Sub Saharan Africa in particular. For instance, with average annual increases between 0.8 and 2.6 percentage points, all LACs outpaced the USA between 1830 and 1870 ( 0.6 per cent), while Nigeria (1.9 per cent) and Malawi (3.3 per cent) were considerably faster than any LAC in the second half of the $20^{\text {th }}$ century. Within Latin America the negative correlation between the timing and pace of expansion can not be observed. Early movers such as Argentina, Chile and Costa Rica recorded an average annual increase of 1.1 per cent, which equals the Latin American average. Nevertheless, the typical late movers Honduras and Nicaragua achieved average annual increases of 1.4 per cent and 2.1 per cent respectively, clearly higher than the regional average. The Dominican Republic, Venezuela, Peru and El Salvador also had higher rates of expansion during the mid$20^{\text {th }}$ century.

Part of the explanation for the relatively rapid expansion of mass education in Latin America in the $20^{\text {th }}$ century relates to the comparatively equal gender distribution of primary school enrolment. Appendix Table A.2 shows the percentage share of females in primary school enrolment for the years 1890-1902, 1950-54 and 1990-97. The table also shows the female shares in secondary and tertiary enrolment for the latter two periods. It turns out that, even in the early part of the transition, female shares in primary schooling were more or less comparable to those in the most advanced European economies and the USA. This remained the case throughout the $20^{\text {th }}$ century. The unweighted Latin American average female share in primary school enrolment was 44.3 per cent in the period $1890 / 1902^{24}$. This figure gains some weight when compared to the gender distribution in European countries such as Portugal and Greece and Asian countries like Japan, India, Sri Lanka and Myanmar. Comparatively low levels of gender inequality can also be noted in secondary and tertiary education. In the 1950s the average share of females in secondary education was 41.1 per cent and this

${ }^{23}$ It is assumed that countries reporting an enrolment rate of $<95$ per cent at the start of a particular decade will achieve a full enrolment rate $(<100$ per cent $)$ in the same decade.

24 Since this average includes many of the more advanced LACs at that time and excludes many of the lesser advanced, this is probably an overestimation. Nevertheless, the estimate for Guatemala of 32.8 per cent shows that even in one of the poorest LACs, the gender distribution was fairly egalitarian compared to the Asian countries listed in Table A.2. See also Frankema (2009, pp. 93-97). 
number increased to 52 per cent in the 1990s. Although it appears that some of the Asian countries such as Japan and Sri Lanka had overtaken the Latin American average in the 1950s, the figure still compares well to such countries as Greece and Spain, let alone the developing countries in Africa and the Middle East. In tertiary education the figure of 23.8 per cent in the 1950 s is even higher than in the Netherlands or Switzerland ${ }^{25}$.

In sum, the expansion of mass education was delayed, but once underway it did not move distinctively slower or faster than could be expected on the basis of a global comparison of expansion rates. There were sufficient resources on the aggregate economic level that could have been devoted to educational expansion, but the resistance to redistributive taxation in combination with low perceived benefits of education in societies characterised by confined opportunities of social mobility distorted the required incentives to invest in primary schooling. These forces weakened in the course of the $20^{\text {th }}$ century. Given the historical relationship between economic inequality and the delay in enrolment expansion, it is quite remarkable that the gender distribution of enrolment has been quite egalitarian, even in comparison to some of the early industrialised countries, but especially in comparison to Asian, African and Middle Eastern countries. The fact that primary education became as open to girls as it was to boys helped gross enrolment rates to catch up rapidly with the advanced OECD countries.

\section{DID QUANTITY CORRESPOND WITH QUALITY?}

In a recent paper Hanushek and Woessmann (2009b) point out that in view of their comparative levels of school attainment and per capita income around 1960, Latin American countries dramatically underperformed in the international student test scores of reading, math and science that became available around the turn of the 21 st century. They argue that the poor quality of Latin American mass education impacted negatively on the comparative development of cognitive skills and that this is one of the main reasons for sluggish growth rates in the post-1960 era. However impressive the results of their formal regression analyses, it must be pointed out that their educational quality measures suffer from two major shortcomings: only seven LACs ever participated in any of the international science or math tests and the only data available are for 1997 or later years ${ }^{26}$.

This section adopts a recently developed indicator of educational development which focuses on some other qualitative aspects of primary and second-

25 These findings are also supported by comparative analyses of gender inequality in literacy rates, see Berges (2009, pp. 9-10).

26 The countries included are Argentina, Brazil, Chile, Colombia, Mexico, Peru and Uruguay. See Hanushek and Woessmann (2009b, pp. 6-8, and their data appendix, table A.1). 
ary schooling. The indicator is only a very indirect and incomplete measure of educational quality, but it has the advantage that it can be constructed and compared across a large number of developed and developing countries from 1960 onwards. The methodology has been developed in studies by Frankema and Bolt (2006) and Frankema (2008a). The central idea is that the percentage distribution of grade enrolment rates in primary and secondary schooling contains information on grade repetition and pre-completion drop-out rates, which in turn provides insight into the effectiveness of educational systems with respect to extorting regular school attendance and supporting children in the process of grade promotion towards school completion. Before discussing the indicator in more detail, it is important to note that school attendance and drop-out rates do not exclusively reflect aspects of educational quality. They are also likely to reflect some aspects of the socio-economic environment of families with children. Hence, there are obvious limitations to the measure presented below and the only way to reduce these limitations is to complement this indicator with other indicators on long run educational development, such as the school expenditure approach adopted in section 5.

Data on grade enrolment rates are available from UNESCO's Yearbook of Statistics for five-year intervals from the 1950s onwards and can be standardized for comparative purposes (see for a source description further below) ${ }^{27}$. The grade enrolment distribution in primary and secondary education can be linked using the absolute number of pupils enrolled in both levels of schooling and weighting their respective percentage distributions according to the following formulas,

$$
\frac{X_{p}}{X_{p}+X_{s}} * g_{p i} \quad, \quad \frac{X_{s}}{X_{p}+X_{s}} * g_{s i}
$$

Where $X_{p}$ and $X_{s}$ refer to the total number of students enrolled in, respectively, primary and secondary schools and $g_{p i}$ and $g_{s i}$ refer to the percentage share of students enrolled in the $i$ th grade of primary and secondary school ${ }^{28}$. Depending on the total amount of grades in primary and secondary education, a standardised distribution can be obtained for ten to twelve grades for 92 developing countries (World Bank classification) and 32 OECD countries from 1960 onwards.

Table 2 presents two examples of this standardised grade enrolment distribution in Argentina and Canada for the year 1960. In the hypothetical scenario that each grade contains exactly the same amount of students, all

\footnotetext{
27 From 1999 onwards the data are accessible online [UNESCO Institute for Statistics (UIS)].

28 In some countries there is an overlap in the final grades of primary and the first grades of secondary schooling that requires extra calculations to link the series adequately. Generally the students in the «intermediate» grades were added to the first grades in secondary education.
} 
TABLE 2

THE PERCENTAGE DISTRIBUTION OF GRADE ENROLMENT IN ARGENTINA AND CANADA OVER 12 CONSECUTIVE GRADES IN PRIMARY AND SECONDARY SCHOOLING, 1960

\begin{tabular}{|l|c|c|c|c|c|c|c|c|c|c|c|c|}
\hline \multicolumn{1}{|c|}{ Grade } & $\mathbf{1}$ & $\mathbf{2}$ & $\mathbf{3}$ & $\mathbf{4}$ & $\mathbf{5}$ & $\mathbf{6}$ & $\mathbf{7}$ & $\mathbf{8}$ & $\mathbf{9}$ & $\mathbf{1 0}$ & $\mathbf{1 1}$ & $\mathbf{1 2}$ \\
\hline Argentina & 21.3 & 14.0 & 13.8 & 12.0 & 10.2 & 8.7 & 7.2 & 4.2 & 2.9 & 2.4 & 1.8 & 1.4 \\
\hline Canada & 11.9 & 11.1 & 10.8 & 10.3 & 10.0 & 9.7 & 9.3 & 8.4 & 7.1 & 5.1 & 3.8 & 2.4 \\
\hline
\end{tabular}

Sources: UNESCO, Statistical Yearbook 1972 (author's own calculations).

twelve grades would contain $100 / 12=8.33$ per cent. In practice, this distribution is always skewed towards the lower grades because some children leave school earlier than others. Most OECD countries reveal a pattern comparable to Canada's, where the percentage shares decline substantially only from the $9^{\text {th }}$ grade on. At this point some children have completed their secondary school. Developing countries reveal patterns that are more comparable to Argentina's, or even much more skewed. Assuming, for the moment (we will discuss the validity of this assumption and possible solutions later), that the influx of children in education is more or less constant, a skewed distribution is caused by children who repeat one or several of the lower grades for one or more years and drop out before reaching the higher grades. The weak record of Latin America regarding grade promotion and school completion has been acknowledged in the literature, but to our knowledge there have been no other attempts to frame it in a standardized indicator of grade enrolment distribution suitable for inter-temporal and global cross-county comparisons ${ }^{29}$.

Figure 3 illustrates the importance of such a measure. In Colombia the reported gross enrolment rate in 1970 was 102 per cent and in South Korea 104 per cent (UNESCO, Statistical Yearbook 1974). So basically all children of the relevant age group in both countries were registered as enrolled in primary education. Yet, the grade enrolment distribution reveals an enormous contrast. In Colombia high rates of grade repetition and pre-completion drop out rates skewed the grade enrolment distribution towards the lower grades. Only a small group of children completed primary schooling and enrolled in secondary schooling. Those who did, had a relatively high chance of completing secondary school compared to children in primary school. Korean children, on the other hand, were much more evenly distributed across the first six grades of primary school.

29 See for instance Schiefelbein (1992), Martin (1994) or Birdsall, Ross and Sabot (1997, pp. 96-97). 
FIGURE 3

PERCENTAGE DISTRIBUTION OF GRADE ENROLMENT IN COLOMBIA AND SOUTH KOREA, 1970

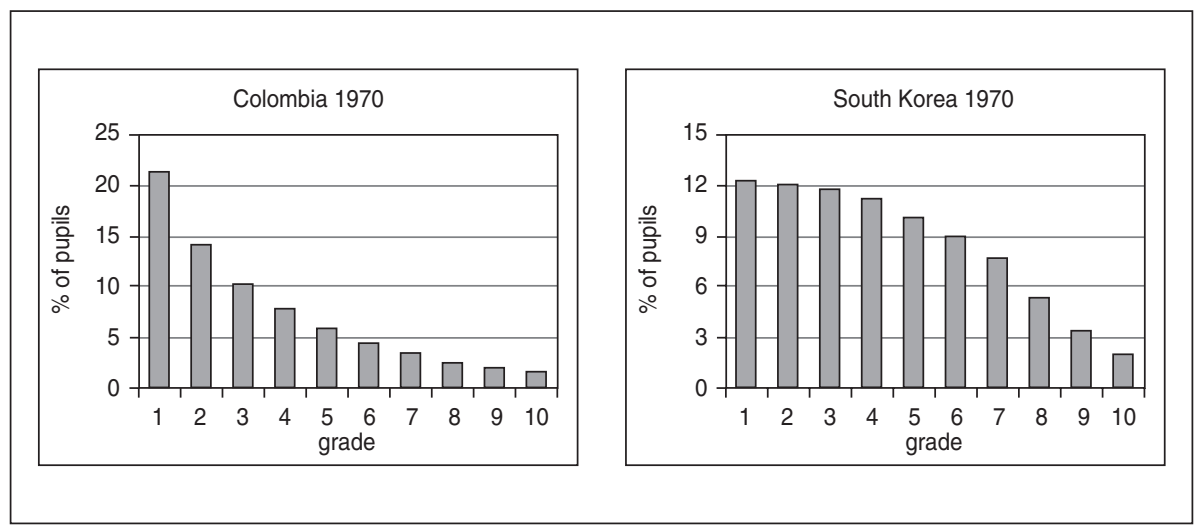

Sources: UNESCO, Statistical Yearbook 1972 and 1978-1979 (author's own calculations).

Notes: three year moving average of twelve consecutive grades in primary and secondary schooling.

This simple comparison demonstrates two major limitations of using gross enrolment rates for comparative purposes. First, gross enrolment rates do not capture any information concerning the variation of school careers of students, which reflect an important part of educational quality. Second, high grade repetition rates tend to inflate enrolment rates because children attend more years than scheduled at the start of their school careers.

Irregular school attendance goes a long way in explaining the phenomena of grade repetition and pre-completion drop out. Children can be officially registered as enrolled in primary school without attending in practice. Absenteeism has multiple causes that are related to a lack of financial means, be it private incomes or government subsidies, to cover school expenses. Distance to schools in rural areas may be prohibitive as well as the overcrowding of schools, health problems of the child (undernourishment), child labour, a lack of perceived interest of schooling by parents, a lack of support and attention by teachers, insufficient monitoring of attendance and performance, and so on and so forth. Brazil is one of those LACs in which the problems of absenteeism and irregular school attendance resulted in a dramatic failure of its primary education system. In 195653.1 per cent of all Brazilian pupils were enrolled in the first grade, 21.8 per cent in the second, 15.5 per cent in the third and 9.7 per cent in the final fourth grade. Moreover, 42.7 per cent of the children left school without ever passing the first grade and over 70 per cent left school before completing four years of education. Out of the other 30 per cent, the majority of pupils took five, six 
or seven years to finish four grades ${ }^{30}$. Referring to the poor regions in the North East of Brazil one report states that,

«...retardation in the primary schools reaches alarming proportions, expanding and enlarging the school age band, multiplying the first grades, crowding the classroom, and dividing the school periods into two, three, or even four sessions because there are not enough funds to build more schools» ${ }^{31}$.

The distributive information contained in grade enrolment rates can be standardized by estimating the chance that children entering school will have a smooth school career up to completion of either primary or secondary schooling. A possible method is to take the ratio of the percentage share of students in grade 1 to the shares in grade 6,9 or 12 . The disadvantage of this approach is that such a comparison is sensitive to year-to-year fluctuations that occasionally occur in school enrolment. An alternative method is to average out these fluctuations by taking a weighted measure of students enrolled in more than one grade. This will also reveal a larger part of the underlying structure of the distribution. Any ratio of grade enrolment rates is feasible once we normalise the equation for the number of grades involved. The grade distribution ratio (GDR hereafter) can thus be defined as,

$$
\text { GDR 1-N }=\frac{\sum_{i=(n+1), N} g_{i}}{\sum_{i=1, n} g_{i}} * \frac{n}{N-n}
$$

Where $\mathrm{N}$ is the total number of grades and $g_{\mathrm{i}}$ is the percentage share of children enrolled in the $i$ th grade. Since most countries have adopted a six grade elementary curriculum, a measure including the first six grades gives the best fit to standardize the grade distribution indicator for primary education. Assuming that the influx of pupils is constant over time, the ratio of the grades 4 to 6 over 1 to 3 expresses the chance that a pupil in grades 1 to 3 reaches the higher grades 4 to 6 without repeating grades or dropping out. Hence, the GDR 1-6 can be defined as,

$$
\text { GDR 1-N }=\frac{\sum_{i=4-6} g_{i}}{\sum_{i=1-3} g_{i}}
$$

30 UNESCO (1958, p. 172).

31 UNESCO (1958, p. 172). 
So far, the implicit assumption has been made that the influx of pupils is constant over time. A growing (or declining) school-age population skews the grade enrolment distribution, however, if it implies that each year more children enroll than in the previous year, other things being equal. The countries under consideration here almost all witnessed rapid increases in their school-age populations (the 5 to 14 year old category) over the period 19602005. Demographic growth explains the bulk, between 75 and 100 per cent, of year to year fluctuations in total enrolment. The demographic database of the UN provides population figures for the age group 5 to 14 from 1950 onwards (five year intervals, see UN, World Population Prospects 2004). On the basis of these data Frankema has estimated that demographic growth can distort the GDR by a maximum of ca. $0.10^{32}$.

Table 3 shows the estimates of the adjusted grade distribution ratio's (GDR 1-6) in the period 1960-2005 for five developing regions in the world. The regional averages are weighted according to the total number of students enrolled per country. The table shows that the initial levels of the Latin American GDR in the 1960s were staggeringly low. The weighted GDR of 0.42 for Latin America even compares poorly to the 0.59 of Sub Saharan Africa. Indeed, in Sub Saharan Africa at that time poor educational development is not primarily reflected by a skewed distribution of grade enrolment rates (although it is very skewed), but rather by the even more fundamental

TABLE 3

INTERREGIONAL COMPARISON OF GRADE DISTRIBUTION RATIOS (1-6), 1960-2005

(Population-weighted averages)

\begin{tabular}{|l|c|c|c|c|c|}
\hline & $\mathbf{1 9 6 0 / 5}$ & $\mathbf{1 9 7 0 / 5}$ & $\mathbf{1 9 8 0 / 5}$ & $\mathbf{1 9 9 0 / 5}$ & $\mathbf{2 0 0 0 / 5}$ \\
\hline Latin America (19) & 0.42 & 0.57 & 0.64 & 0.68 & 0.84 \\
\hline South \& West Asia (5) & 0.50 & 0.57 & 0.58 & 0.73 & 0.74 \\
\hline East Asia \& Pacific (7) & 0.63 & 0.72 & 0.72 & 0.93 & 0.87 \\
\hline Sub Saharan Africa (19) & 0.59 & 0.68 & 0.79 & 0.80 & 0.75 \\
\hline North Africa \& Middle East (10) & 0.66 & 0.79 & 0.81 & 0.90 & 0.88 \\
\hline
\end{tabular}

Sources: UNESCO, Statistical Yearbook, various issues 1962-1998 and UNESCO, Institute for Statistics, www.uis.unesco.org.

Notes: Latin American countries included: Argentina, Bolivia, Brazil, Colombia, Costa Rica, Chile, Cuba, Ecuador, El Salvador, Guyana, Honduras, Mexico, Nicaragua, Panama, Paraguay, Peru, Trinidad \& Tobago, Uruguay, Venezuela; South \& West Asian countries included: Afghanistan, Bahrain, Bangladesh, India and Iran; East Asian \& Pacific countries included: Hong Kong, Indonesia, South Korea, Laos, Malaysia, Philippines, Thailand; Sub Saharan African countries included: Botswana, Burkina Faso, Congo Rep., Ethiopia, Gabon, The Gambia, Ghana, Ivory Coast, Kenya, Lesotho, Madagascar, Mauritania, Mauritius, Niger, Nigeria, Rwanda, Senegal, Uganda, Zambia; North African \& Middle Eastern countries included: Iraq, Israel, Jordan, Kuwait, Morocco, Qatar, Saudi Arabia, Syria, Tunisia, Turkey.

32 Frankema (2008a, p. 144). 
gap between children who go to school and those who do not attend at all. Table 3 shows that over time, while gross enrolment rates expanded rapidly in Sub Saharan Africa, grade enrolment ratios remained low. This seems to be in line with the argument of Clemens (2004) that an excessively rapid expansion of primary education can have (severe) repercussions for the quality of the education system. In this respect it is important to note that in terms of grade promotion and school completion, LACs performed even below the standard of the current developing world. So, one of the things that this analysis may point out is that the attempt of many LACs to advance mass education took place at the expense of educational quality in a similar way as can be observed for Sub Saharan African countries at present. Of course, the rate of expansion is not, in itself, causing the problem. It is rather the case that all the crucial conditions for rapid expansion have to be met.

Figure 4 lists the 57 countries from the sample that achieved full gross primary school enrolment rates in the period 1960-2005 and the adjusted GDRs 1-6 in the first half of that particular decade. In particular, LACs turn out to have combined full enrolment rates with very low GDRs. For instance, in 1980, Jordan achieved full gross enrolment rates and complete grade enrolment equalization in the same decade, whereas Brazil and Nicaragua achieved full gross enrolment rates with an adjusted GDR of only 0.27 and 0.32 respectively. Or compare Chile in the 1960s with South Korea or Singapore, or Colombia in the 1970s with Zambia, Sri Lanka and Mauritius. All LACs obtained a GDR below 0.75 when achieving full enrolment.

Focusing on the time lag between the achievement of full primary school enrolment rates and the GDR passing a level of 0.95, we also find striking global differences. In Malaysia, Singapore and Jordan there was no time lag whatsoever. In these countries the development of the educational system not only guaranteed enrolment for all children, but also effectively organized the system of grade promotion and prevented children from dropping out of school before completion at the same time. South Korea, Cyprus and Mauritius witnessed a one decade time-lag between reaching both goals. Yet it took Argentina five decades and Chile four decades to equalise their grade enrolment distribution after having achieved a gross enrolment rate of 100 per cent or above! Panama and Uruguay are currently approaching a five decade lag. Such differences indeed make the overt limitations of educational attainment figures based on school enrolment rates clear.

In sum, the Latin American strategy of expanding mass education can be characterised as «enrolment over completion». As Clemens (2004: p. 1) suggests, the combination of rapid enrolment expansion and quality maintenance is not self-evident. The problem of irregular school attendance was only addressed in a more structured manner in the last two decades of the $20^{\text {th }}$ century. In a large effort to improve the quality of primary schooling many LACs accomplished grade distribution ratios close to 1.00 . From a global comparative perspective, however, taking the middle-income status 
FIGURE 4

GRADE DISTRIBUTION RATIO (1-6) IN THE FIRST DECADE OF FULL PRIMARY SCHOOL ENROLMENT, 1960-2005

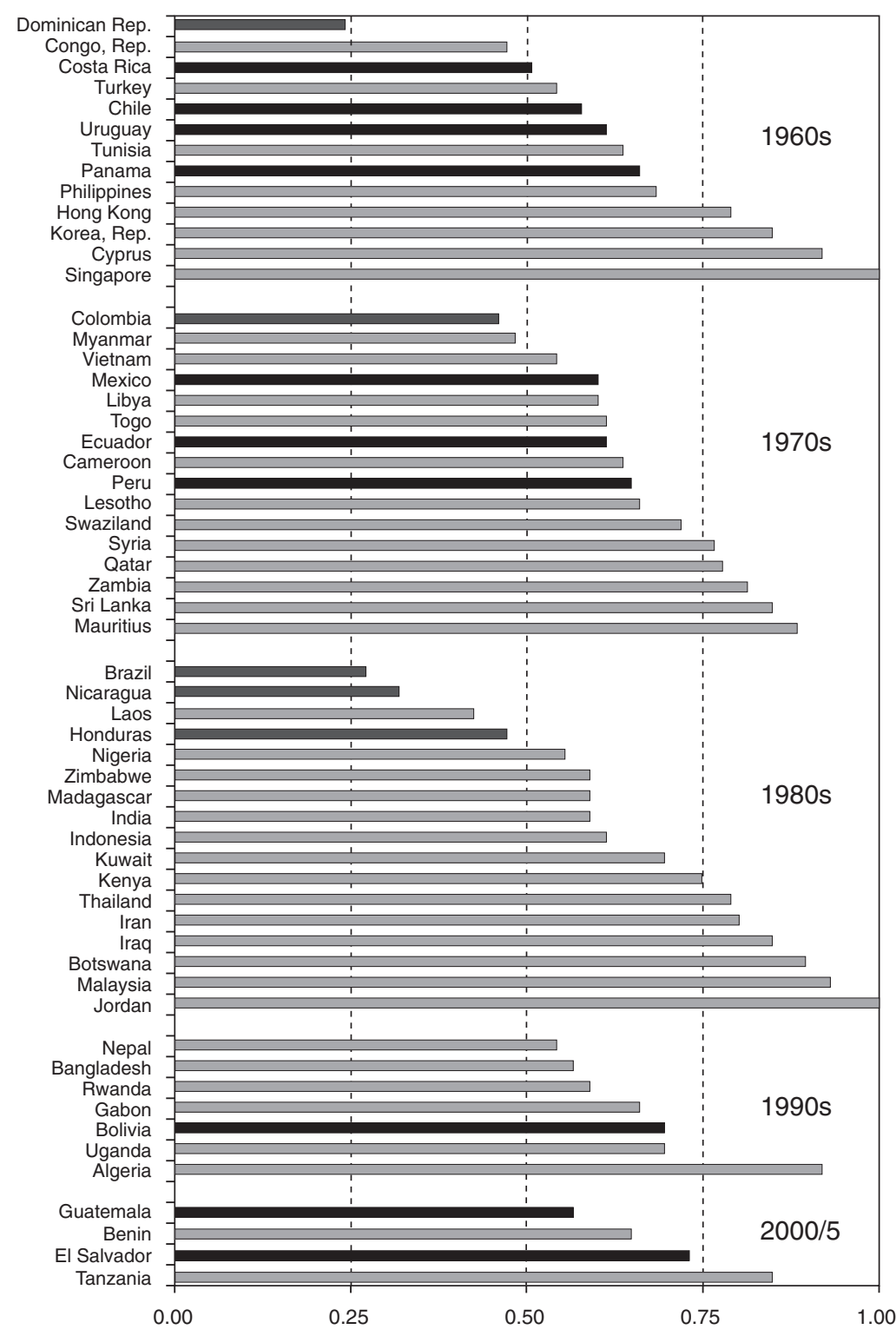

Sources: UNESCO, Statistical Yearbook, various issues 1966-1999; UNESCO, Institute for Statistics (UIS), www.uis.unseco.org. GDRs from Frankema (2008a). 
of the region into account, this happened rather late in the game. Finally, it is interesting to explore whether there is a relationship between the GDR estimates and the more recent international student test scores, despite the different timeframe of the data and the very limited number of observations (30). We performed two simple linear OLS regressions of the average GDR 1960-2005 and 1990-2005 respectively on the average score for cognitive skills presented by Hanushek and Woessmann (2009a: table B3, pp. A15-A17). The first regression produced a significant relationship at the 1 per cent level ( $p$-value of 0.0015 ) with an R-squared of 0.307 . The second regression was significant at the 1 per cent level (p-value of 0.0006 ) with an $\mathrm{R}$-squared of $0.351^{33}$. These results are, indeed, reassuring.

\section{THE DISTRIBUTION OF PUBLIC EDUCATION EXPENDITURE: EVIDENCE FOR A POLITICAL ECONOMY ARGUMENT?}

How can we explain that quality improvements lagged behind enrolment expansion? As mentioned above, an influential current in the historical literature opts for a political economy explanation: in the high inequality countries of Latin America the politically influential economic elites tried to prevent a substantial redistribution of income through tax-supported public education. This section will focus on the question whether, from a global comparative perspective, the distribution of public expenditure on education supports that idea. Political decisions regarding the allocation of public resources often reveal the preferences and influence of the most powerful interest groups in society. Since tax-supported expansion of mass education almost inevitably produces a progressive redistribution of income, other things being equal, it is important to find out how much of the public budget is spent on public primary education relative to other types of education. Since the literature widely agrees that the social returns of primary schooling are generally higher than secondary or tertiary schooling, Peter Lindert argues that the per student ratio of expenditure on primary versus non-primary schooling should in any case be smaller than one. Lindert shows that in the OECD countries the ratio is typically around 50 per cent ${ }^{34}$. This seems to be a good yardstick to keep in mind when exploring the distribution of government spending in Latin America.

Some words of caution with regard to comparing public expenditure figures across countries and over time are required in advance, however. First, the discussion presented below is exclusively based on current educational expenditure estimates. Capital expenditure on education is subject to highly variable definitions and often indivisible with respect to levels of education.

\footnotetext{
33 Regressions were estimated with Eviews 6.0.

34 See Lindert (2009, pp. 23-25 and table 4, pp. 38-39).
} 
Second, the analysis only includes public expenditure. As the private sector may form a substantial share of educational expenditure, our cross-country comparison only traces differences in tax-supported educational investments. Third, in some countries a significant share of educational spending is accounted for at a sub-national level, which is not always included in the reports. In this case there is no basis for an accurate cross-country comparison. The notes below the tables will address some of these issues in more detail $^{35}$. It should further be mentioned that expressing educational expenditure as a share of GDP involves some endogeneity: the expenditure share in low income countries tends to be overstated via the lower denominator. Higher costs of education, in particular teacher salaries, may neutralize (part of) this bias, although higher teacher salaries can also reflect higher quality. Since the crude data do not allow us to control for these factors, the figures can only be interpreted correctly when bearing such shortcomings in mind.

An overview of current public educational expenditure as a percentage share of GDP in Latin America and a selection of non-LACs is presented in Appendix Table A.3. The data refer to the period 1950-1995. The table shows that the general trend in Latin American public education expenditure during the post-war era is upward sloping. With the exception of the temporary setback during the "lost decade» of the 1980s, expenditure shares appear to have increased almost continuously in virtually all LACs. The early postwar expansion of the education budget followed in the wake of national economic development plans, which acknowledged that a well educated labour force was an absolute requirement for the continuation of structural change and the successful implementation of industrialisation programs ${ }^{36}$. The recovery of educational investments after the prolonged recession of the 1980s, in particular, testifies to the commitment of Latin American governments to raise levels of education. Within just 5 years between 1990 and 1995 expenditure shares increased from 3.0 to 3.7 per cent of GDP.

As a region, Latin America may be gradually approaching the OECD target of 6.0 per cent of GDP, but the figures for Canada and the Netherlands show that the percentage shares in most LACs are still significantly lower than in the OECD countries ${ }^{37}$. The Latin American average is comparable to the expenditure shares in India and Thailand, higher than in the Philippines, but lower than in Malaysia. The intra-regional variation in expenditure shares is large, however. Jamaica and Costa Rica rank among the highest investors. In Haiti, the Dominican Republic, Guatemala and El Salvador public spending clearly lags, especially taking their comparatively low GDP levels into account. There are some other poor LACs such as Bolivia, Nicaragua and

\footnotetext{
35 For a more elaborate discussion of comparability problems see Lindert (2004, pp. 142-144).

36 ECLAC (1968).

37 The average OECD expenditure share in 2005 was 6.2 per cent. See OECD (2005, Chap-
} ter B). 
Honduras, which dramatically raised public expenditure on education in the last two decades of the $20^{\text {th }}$ century. In Brazil and Mexico the increase in educational expenditure has also been impressive, especially given the fact that in these two countries a considerable amount of educational spending is made at sub-national levels, which are not included in the figures.

Yet, when looking at the level-distribution of this spending the picture becomes less favourable. Table 4 presents the ratio of public expenditure

TABLE 4

RATIO OF PUBLIC EXPENDITURE PER STUDENT ENROLLED IN SECONDARY AND TERTIARY EDUCATION TO PRIMARY EDUCATION $(=1.0)$, LATIN AMERICA VERSUS A SELECTION OF NON LATIN AMERICAN COUNTRIES, 1950-1995

\begin{tabular}{|l|c|c|c|c|c|c|c|c|c|c|}
\hline & \multicolumn{5}{|c}{ Secondary education } & \multicolumn{5}{c|}{ Tertiary education } \\
\hline & $\mathbf{1 9 5 0 / 5 5}$ & $\mathbf{1 9 6 0 / 6 5}$ & $\mathbf{1 9 7 0 / 7 5}$ & $\mathbf{1 9 8 0 / 8 5}$ & $\mathbf{1 9 9 0 / 9 5}$ & $\mathbf{1 9 5 0 / 5 5}$ & $\mathbf{1 9 6 0 / 6 5}$ & $\mathbf{1 9 7 0 / 7 5}$ & $\mathbf{1 9 8 0 / 8 5}$ & $\mathbf{1 9 9 0 / 9 5}$ \\
\hline Argentina & 2.7 & 2.7 & 1.6 & 2.0 & 1.1 & 5.8 & 4.4 & 2.2 & 4.4 & 1.8 \\
\hline Chile & & 3.7 & 2.0 & 1.3 & 0.9 & & 29.8 & 11.0 & 10.4 & 2.2 \\
\hline Colombia & 5.1 & 4.1 & & 1.2 & 1.4 & 18.0 & 34.2 & & 5.7 & 4.6 \\
\hline Costa Rica & & 2.2 & $1.8^{*}$ & 2.0 & 1.6 & & 9.2 & $5.8^{*}$ & 5.7 & 4.8 \\
\hline Cuba & 3.3 & & & 1.8 & 1.3 & 1.4 & & & 2.3 & 2.0 \\
\hline Ecuador & & 4.9 & 3.1 & 1.1 & 2.2 & & $17.6 *$ & 3.8 & 4.4 & 8.1 \\
\hline El Salvador & & 2.2 & 2.3 & 1.1 & & & 19.6 & 22.5 & 11.4 & \\
\hline Guatemala & & 4.0 & 2.0 & 1.6 & 0.8 & & 10.9 & 7.3 & 8.1 & 7.1 \\
\hline Honduras & 5.4 & 2.5 & 2.4 & 1.5 & 1.6 & 18.6 & 15.9 & 14.2 & 9.9 & 7.5 \\
\hline Mexico & & 3.5 & 2.2 & 1.1 & 1.5 & & 12.5 & 8.6 & 11.8 & 4.0 \\
\hline Nicaragua & & 2.9 & 2.0 & 1.4 & & & 7.8 & 6.8 & 9.3 & \\
\hline Panama & & 2.7 & 1.8 & 1.2 & 1.1 & 5.7 & 4.8 & 7.2 & 3.2 & 3.8 \\
\hline Paraguay & 5.3 & $4.1 *$ & 2.0 & 3.1 & $1.1 *$ & 27.4 & $17.2^{*}$ & 13.6 & 11.5 & $8.5 *$ \\
\hline Uruguay & & 2.3 & 1.4 & 1.5 & 1.0 & & 9.7 & 6.8 & 3.0 & 3.4 \\
\hline Venezuela & 8.1 & 2.6 & 1.6 & 0.8 & 3.2 & 40.0 & 15.5 & 8.5 & 8.6 & 14.8 \\
\hline LA average & $\mathbf{5 . 0}$ & $\mathbf{3 . 2}$ & $\mathbf{2 . 0}$ & $\mathbf{1 . 5}$ & $\mathbf{1 . 5}$ & $\mathbf{1 6 . 7}$ & $\mathbf{1 4 . 9}$ & $\mathbf{9 . 4}$ & $\mathbf{7 . 3}$ & $\mathbf{5 . 6}$ \\
\hline & & & & & & & & & & \\
\hline Finland & 1.8 & 1.5 & 0.4 & 1.2 & 0.9 & 3.0 & 2.6 & 0.8 & 1.8 & 1.7 \\
\hline France & $2.1 *$ & 3.1 & 1.4 & 1.2 & 1.1 & 5.4 & 8.1 & 2.5 & 1.6 & 1.0 \\
\hline
\end{tabular}


TABLE 4 (Continued)

\begin{tabular}{|c|c|c|c|c|c|c|c|c|c|c|}
\hline & \multicolumn{5}{|c|}{ Secondary education } & \multicolumn{5}{|c|}{ Tertiary education } \\
\hline & $1950 / 55$ & $1960 / 65$ & $1970 / 75$ & $1980 / 85$ & $1990 / 95$ & $1950 / 55$ & $1960 / 65$ & $1970 / 75$ & $1980 / 85$ & 1990/95 \\
\hline Hungary & 5.1 & 2.2 & 0.9 & 1.1 & 0.2 & 15.5 & 14.8 & 5.2 & 6.1 & 1.2 \\
\hline Netherlands & 2.7 & 2.1 & 1.6 & 1.2 & 0.2 & 6.3 & $12.8^{*}$ & $8.1^{*}$ & 3.4 & 0.3 \\
\hline Portugal & 5.0 & 4.0 & & 4.1 & 0.3 & 14.3 & 8.5 & & 4.5 & 0.2 \\
\hline Japan & 1.3 & 1.1 & 0.5 & 1.1 & 1.0 & 5.7 & 8.9 & 2.5 & 1.7 & 0.8 \\
\hline Korea, Rep. & 0.5 & 2.5 & 0.3 & 0.8 & 0.9 & 15.3 & 2.2 & 1.7 & 1.1 & 0.4 \\
\hline Malaysia & 2.4 & 1.9 & 1.5 & 1.7 & 1.9 & & $26.4^{*}$ & 17.3 & 8.1 & 7.7 \\
\hline Singapore & 2.6 & 1.4 & 1.8 & 1.6 & 1.6 & & 7.3 & 7.8 & 7.2 & 4.4 \\
\hline Thailand & 2.3 & 4.9 & 1.9 & 1.2 & 0.8 & 22.3 & 14.6 & 12.1 & 1.5 & 1.7 \\
\hline Kenya & 17.2 & 12.9 & 10.3 & 3.1 & 2.5 & $23.3 *$ & 170.4 & 121.8 & 43.2 & 54.6 \\
\hline Malawi & 67.4 & 12.5 & 20.8 & 13.5 & 6.6 & & $268.2 *$ & 259.0* & 146.8 & 160.7 \\
\hline Mauritius & & 7.9 & 6.2 & 1.3 & 1.5 & & 14.2 & 6.5 & 22.6 & 14.2 \\
\hline Tanzania & 2.5 & 14.8 & 9.2 & 12.3 & & 46.3 & 165.7 & 107.9 & 146.1 & \\
\hline Togo & & $3.3^{*}$ & 5.4 & 3.8 & 3.8 & & $11.3^{*}$ & 22.9 & 124.5 & 64.9 \\
\hline
\end{tabular}

Sources: UNESCO (1958) World Survey of Education; UNESCO, Statistical Yearbook, various issues 1966-1998.

Notes: To calculate the expenditure per student per level a one year difference between the expenditure report and the observed number of students enrolled was allowed. In a few cases interpolation or extrapolation techniques were employed to estimate the number of students enrolled. * Costa Rica 1970/75: figures refer to 1968; Ecuador 1962: Tertiary education includes universities only; France 1954: Secondary education excluding vocational and teacher training; Honduras 1970: Tertiary education includes universities only; Kenya 1954: Tertiary education consists exclusively of teacher training at secondary and tertiary level; Kenya 1971: Tertiary education includes universities only; Malawi 1965 and 1970: Tertiary education includes universities only; Malaysia 1964: Tertiary education includes universities only; Netherlands 1962 and 1971: Tertiary education includes universities only; Paraguay 1960/65: figures refer to 1966; Paraguay 1990/95: figures refer to 1996; Togo 1960/65: figures refer to 1966.

per student enrolled in secondary and tertiary education over primary education for the period 1950-1995. Due to the large amount of missing observations the averages have to be interpreted with care, especially for the years 1950/5. Again large intra-regional differences appear, but some general patterns can also be discerned. In the early post-war period, when gross enrolment rates were increasing rapidly in almost all LACs, inequality in 
the distribution of public spending was strikingly large. Tertiary students received almost 15 times as much on average as primary students during the early 1960s. Secondary students also still received 3.2 times as much. One can safely conclude that the expenditure bias towards tertiary education was beyond all reasonable proportions, and is comparable to the distribution in many Sub Saharan African countries today. Most public resources went to the happy few enrolled in tertiary education, who were in most cases the children of the well-off. This flagrant source of inequality has been reduced, even throughout the 1980s, but the expenditure distribution has not approached the standard that each child in primary school on average receives at least an equal tax-supported contribution compared to tertiary education students.

But looking beyond the general regional pattern, the intra-regional differences come to dominate the picture. Argentina, Costa Rica, Panama and Uruguay, the countries identified as «early movers» in section 3, revealed a considerably more egalitarian distribution of educational investment throughout the second half of the $20^{\text {th }}$ century than their neighbours. For instance, in Chile the average tertiary student received almost 30 times as much as the average primary student in the early 1960s. In Argentina this gap was «just» 4.4. The table shows that this enormous difference in the distribution of educational expenditure had disappeared at the close of the $20^{\text {th }}$ century. Despite such examples of regional convergence, some of the cross-country differences remained large. Figure 5 serves to illustrate this graphically, showing the absolute amounts of spending per student in Argentina and Honduras for the years 1954, 1970, 1972/4 and 1991/4. Maddison's (2003) PPP-converted GDP series (in international dollars of 1990) were used to convert the spending figures into absolute amounts. The figure reveals that both countries indeed witnessed a considerable convergence in the ratios of expenditure per student per level. Yet, only in Argentina did this lead to a convergence of absolute amounts of spending. In Honduras the ratio of tertiary to primary spending in 1954 was larger than in 1994 because levels of spending on primary education were incredibly low. Compared to 1954, spending per primary student was approximately six times greater, while spending per tertiary student had increased by a factor of 2.4 . This was insufficient to reduce the absolute gap, however, which only further increased from 111 to 239 dollars.

Hence, the analysis of the distribution of public education expenditure offers strong support to the literature arguing that the relative neglect of public primary education has been driven by the specific features of the political economy in LACs. As Engerman, Mariscal and Sokoloff have argued, high levels of income, asset and wealth inequality in combination with reduced political voice of the poor tended to produce suboptimal educational investment outcomes, that is, when the objective is to maximize social returns. This analysis does not reveal anything about the efficiency with which 
FIGURE 5

TOTAL PUBLIC EXPENDITURE PER STUDENT PER LEVEL OF EDUCATION IN ARGENTINA AND HONDURAS 1954-1994 (IN 1990 GK-US\$)

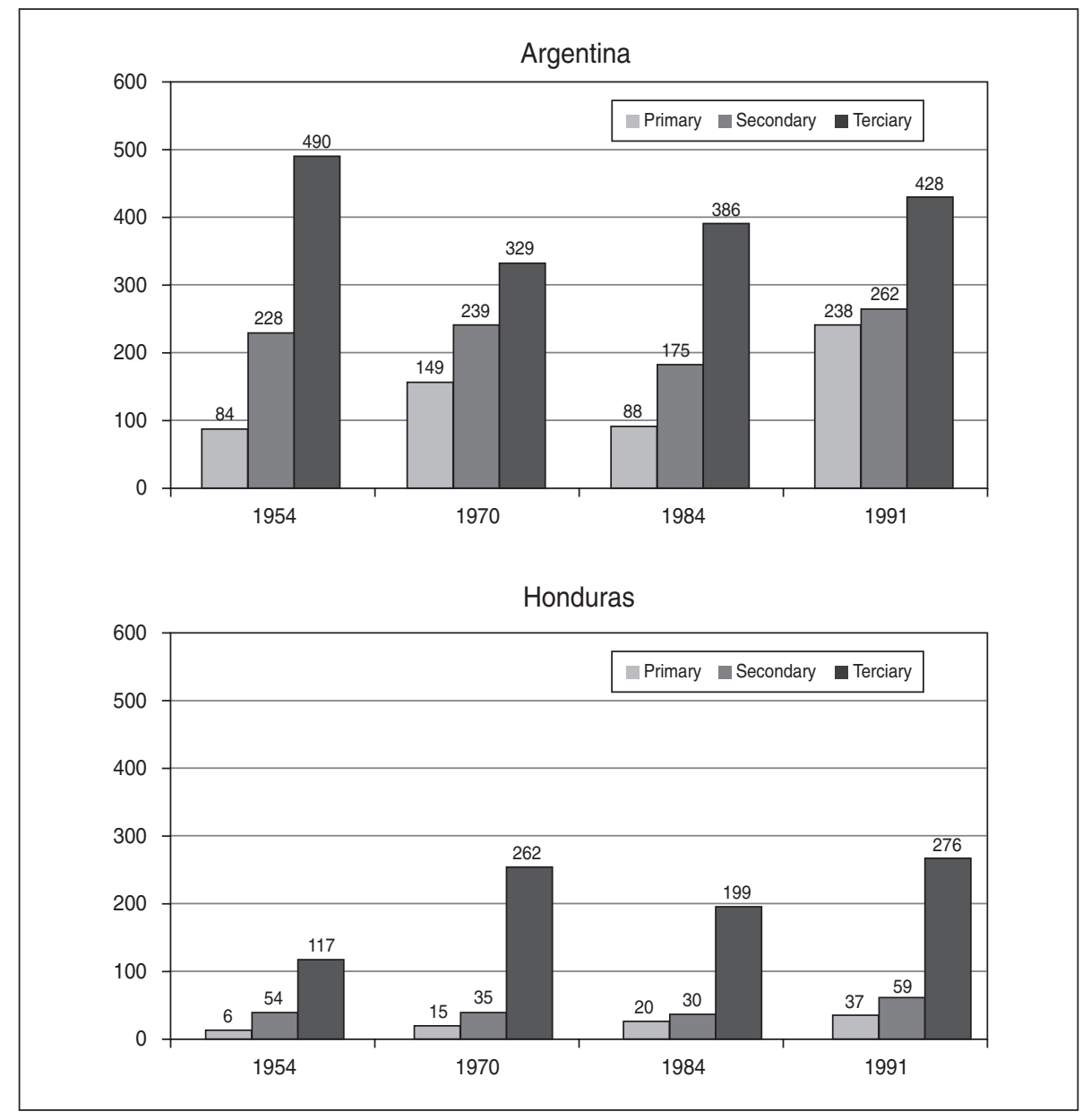

Sources: 1954 educational expenditure data from UNESCO (1958): Data for 1970, 1982/4 and 1991/4 are from UNESCO, Statistical Yearbook, various issues 1966-1998; GDP figures in constant international dollars of 1990 from Maddison (2003).

public money was put to use and thus offers only a partial insight. At the same time, it seems hard to escape the conclusion that it took quite a long time (and in most LACs the process is still incomplete) to reach a distribution of public resources that is better geared to sustained growth and development than several decades ago. 


\section{CONCLUSION}

Despite the evident intra-regional differences, a global comparative assessment of the development of Latin American mass education has revealed at least six region specific characteristics: 1) With respect to average levels of GDP per capita, the transition towards mass public schooling occurred later than in the rest of the New World, Europe and Japan. 2) Once underway, the increase in primary school enrolment was not slower or faster than could be expected on the basis of the patterns observed in the rest of the world: it was faster than in the early industrialising countries in Europe and North America, but it was notably slower than in the poorer developing countries. 3) The expansion of school enrolment came along with a comparatively egalitarian gender distribution from the late $19^{\text {th }}$ century onwards, at least in primary education, which increased the speed of enrolment expansion. 4) The respectable rates of enrolment expansion were not complemented by equally impressive improvements in educational quality, that is, quality defined in terms of a balanced school career in which students progress through consecutive grades on the way to final completion. It took even the most advanced LACs at least four decades to achieve acceptable levels of grade promotion and school completion after having achieved full primary school enrolment rates. Correcting enrolment figures for the grade enrolment ratio demonstrates that the expansion of mass education was much slower than gross enrolment rates suggest. The comparative underperformance in international student test scores and the statistically significant relationship between the GDR and a measure of cognitive skills offer further support for this conclusion. 5) In the post-war era the observed inequality in the grade enrolment distribution was only gradually reduced. This process was partly hampered by the economic crises in the 1980s, but since the start of the 1990s Latin America broke away from this path more rapidly than witnessed before. The advances in the reduction of repetition and precompletion drop-out rates were greater than in other world regions. 6) The distribution of public education expenditure points out that spending was heavily biased towards tertiary education, which basically meant that tax revenues were primarily channelled towards the children of the rich and away from the children of the poor and politically less influential. Although this is just one of many plausible causes of high repetition and drop-out rates in primary schooling, more generally it points to a lack of political priority for improving the quality of public primary schools.

The question as to why LACs were so late in improving the quality of their public education systems has only been tentatively addressed in this paper. It has been argued that the initial conditions of inequality that had evolved in the colonial settler societies had a long lasting impact on the comparative development and distribution of education in post-independent Latin America. As long as the colonial model of the stratified rural society, characterised 
by high land inequality and various forms of labour coercion prevailed, a broadly supported expansion of public education was unfeasible. Landlords needed cheap labour and children of the landed elite were better off with private education. Given the low prospects of social mobility in these premodern rural societies, the demand for popular education was also limited. Hence, fundamental changes in government policies regarding mass education depended largely on the decomposition of the traditional social order and the political stronghold of the landowning elite. Resource-based growth has probably reduced the political as well as economic necessity to reform the public education system. Indeed, the analysis of the education expenditure distribution suggests that a more even distribution of public money toward tertiary and primary schooling has been a painstakingly slow process, although increasing political participation and changing global economic conditions seemed to have turned the odds in favour of mass education in many LACs during the final two decades of the $20^{\text {th }}$ century.

\section{REFERENCES}

Astorga, P.; Berges, A. R., and Fitzgerald, V. (2005): «The standard of living in Latin America during the twentieth century». Economic History Review, 68 (4), pp. 765796.

Bakewell, P. (2004): A History of Latin America. Second edition, Malden MA, Oxford UK: Blackwell Publishing.

BARRo, R. J., and LEE, J. W. (1993): International Comparisons of Educational Attainment. NBER Working Paper No. 4349, Cambridge MA.

- (2001): «International Data on Educational Attainment: Updates and Implications». Oxford Economic Papers, 53, pp. 541-563.

Berges, A. R. (2009): Vertical and Horizontal Inequalities in Human Capital: Educational Attainment and Literacy in Latin America during the Twentieth Century. Working Paper presented at the Mini-Conference «A Comparative Approach to Inequality and Development: Latin America and Europe», Madrid 8-9, May 2009.

Bértola, L.; Camou, M.; Maubrigades, S., and Melgar, N. (2008): Human Development and Inequality in the 20 $0^{\text {th }}$ Century: the Mercosur Countries in a comparative perspective. Universidad Carlos III de Madrid, Working Papers in Economic History, WP 08-06.

Birdsall, N. (1999): Education: The People's Asset. The Brookings Institution Center on Social and Economic Dynamics Working Paper No. 5.

Birdsall, N., and SABOT, R. H. (1994): «Inequality, Exports, and Human Capital in East Asia: Lessons for Latin America», in C. Bradford, Jr. (ed.), Redefining the State in Latin America, Paris: OECD Development Centre and Inter-American Development Bank.

BirdSALL, N.; Ross, D., and SABOT, R. (1997): «Education, Growth and Inequality», in N. Birdsall and F. Jaspersen (eds.), Pathways to Growth. Comparing East Asia and Latin America, Washington: Inter-American Development Bank.

Bourguignon, F. (1993): Growth, Distribution and Human Resources: A Cross-country Analysis. DELTA Working Papers 93-13. 
Brock, C. (1985): «Latin America: An Educational Profile», in C. Brock and H. Lawlor (eds.), Education in Latin America, London, Sydney: Croom Helm Ltd.

CÁrdenas, E.; Ocampo, J. A., and Thorp, R. (eds.) (2000): An Economic History of Twentieth-Century Latin America, Volume I, The Export Age. New York: Palgrave Macmillan.

Castello, A., and Domenech, R. (2002): «Human Capital Inequality and Economic Growth: Some New Evidence». Economic Journal, 112, pp. 187-200.

Clemens, M. A. (2004): The Long Walk to School: International education goals in historical perspective. Center for Global Development Working Paper No. 37.

Cole, H. L.; Ohanian, L. E.; Riascos, A., and Schmitz, J. A. Jr. (2004): Latin America in the Rearview Mirror. NBER Working Paper 11008, Cambridge MA.

Eclac (1968): Education, Human Resources and Development in Latin America. New York: United Nations.

Engerman, S. L.; Haber, S. H., and SoKoloff, K. L. (2001): «Inequality, institutions and differential paths of growth among New World economies», in C. Menard (ed.), Institutions, Contracts and Organizations. Perspectives from New Institutional Economics, Cheltenham UK, Northampton MA: Edward Elgar, pp. 108-134.

EUROMONITOR INTERNATIONAL (2007): World Income Distribution 2006/2007. Fourth edition, London.

Frankema, E. H. P. (2008a): «Comparing the Distribution of Education across the Developing World, 1960-2005: What does the Grade Enrolment Distribution Tell about Latin America?». Social Indicators Research, 88 (3), pp. 437-455.

- (2008b): The Historical Evolution of Inequality in Latin America. A Comparative Analysis, 1870-2000. PhD-thesis, University of Groningen: Ipskamp press.

- (2009): Has Latin America Always Been Unequal? A Comparative Study of Asset and Income Inequality in the Long Twentieth Century. Global Economic History Series, Leiden, Boston: Brill Publishers.

Frankema, E. H. P., and Bolt, J. (2006): Measuring and Analysing Educational Inequality: The Distribution of Grade Enrolment Rates in Latin America and Sub-Saharan Africa. GGDC Research Memorandum GD-86, Groningen.

GREgorio, DE J., and LEE, J. W. (2002): «Education and Income Distribution: New Evidence from Cross-country Data». Review of Income and Wealth, 48, pp. 395-416.

HanusheK, E. A., and Kimko, D. D. (2000): «Schooling, Labor-Force Quality, and the Growth of Nations». The American Economic Review, 90 (5), pp. 1184-1208.

HanusheK, E. A., and Woessmann, L. (2009a): Do Better Schools lead to more Growth? NBER Working Paper No. 14633, Cambridge MA.

- (2009b): Schooling, Cognitive Skills, and the Latin American Growth Puzzle. NBER Working Paper No. 15066, Cambridge MA.

Lindert, P. H. (2004): Growing Public. Social Spending and Economic Growth since the Eighteenth Century, Volume 1. Cambridge MA: Cambridge University Press.

- (2009): Revealing Failures in the History of Education Finance. Working Paper presented at the Mini-Conference "A Comparative Approach to Inequality and Development: Latin America and Europe», Madrid 8-9, May 2009 (version of 17 July 2009).

López, R.; Thomas, V., and Wang, Y. (1998): Addressing the Education Puzzle. The Distribution of Education and Economic Reforms. Policy Research Working Paper 2031, Washington: World Bank.

Maddison, A. (2003): The World Economy: Historical Statistics, Paris: OECD.

Mariscal, E., and SoKoloff, K. L. (2000): «Schooling, Suffrage, and Inequality in the Americas, 1800-1945», in S. Haber (ed.), Political Institutions and Economic Growth 
in Latin America. Essays in Policy, History, and Political Economy, Stanford CA: Hoover Institution Press, pp. 159-217.

Martin, C. J. (1994): Schooling in Mexico. Staying in or Dropping Out. Avebury: Aldershot.

Mitchell, B. R. (2007): International Historical Statistics. The Americas 1750-2005. Sixth edition, New York: Palgrave Macmillan.

Morley, S. (2001): The Income Distribution Problem in Latin America and the Caribbean. Santiago de Chile: UN, ECLAC.

Nehru, V.; Swanson, E., and Dubey, A. (1995): «A New Database on Human Capital Stock in Developing Countries and Industrial Countries: Sources, Methodology, and Results». Journal of Development Economics, 46, pp. 379-401.

OECD (2005): Education at a Glance. OECD Indicators 2005. Paris: OECD.

PARK, Y.B., Ross, D. and SABOT, R.H. (1996): «Educational Expansion and the Inequality of Pay in Brazil and Korea», in N. Birdsall and R. H. Sabot (eds.), Opportunity Forgone: Education in Brazil, Washington: Inter-American Development Bank, Johns Hopkins University Press.

PARRAdO, E. A. (1998): «Expansion of Schooling, Economic Growth, and Regional Inequalities in Argentina». Comparative Education Review, 42 (3), pp. 338-364.

RAM, R. (1990): «Educational Expansion and Schooling Inequality: International Evidence and some Implications». The Review of Economics and Statistics, 72 (2), pp. 266-274.

SAHN, D., and Younger, S. (2004): Changes in Inequality and Poverty in Latin America: Looking Beyond Income to Health and Education. Cornell Food and Nutrition Policy Program Working Paper No. 165.

SchiEfElbein, E. (1992): Redefining basic education for Latin America: lessons to be learned from the Colombian Escuela Nueva. Paris: UNESCO, International Institute for Educational Planning (IIEP).

SOKOLOFF, K. L., and Engerman, S. L. (2000): «History Lessons: Institutions, Factor Endowments, and Paths of Development in the New World». The Journal of Economic Perspectives, 14 (3), pp. 217-232.

SpaldiNG, H. A. Jr. (1972): «Education in Argentina, 1890-1914: The Limits of Oligarchical Reform». Journal of Interdisciplinary History, 3 (1), pp. 31-61.

SPILIMBERGO, A.; Londoño, J. L., and SzÉKELY, M. (1999): «Income Distribution, Factor Endowments and Trade Openness». Journal of Development Economics, 59, pp. 77-101.

Thomas, V.; WANG, Y., and FAN, X. (2001): Measuring Education Inequality: Gini coefficients of Education. Policy Research Working Paper 2525, Washington: World Bank.

Thorp, R. (1998): Progress, Poverty and Exclusion. An Economic History of Latin America in the 20 $0^{\text {th }}$ Century. New York: Inter-American Development Bank, The Johns Hopkins University Press.

UN: World Population Prospects: The 2004 Revision Population Database. www.esa. un.org/unpp/

UN, ECLAC/CEPAL: Anuario Estadistico de America Latina, various issues between 1964-2002.

UNESCO: Statistical Yearbook, various issues between 1962-1999, Paris.

UNESCO (1958): World Survey of Education II. Primary Education, Zürich.

UNESCO: Institute for Statistics (UIS), www.uis.unesco.org.

USAID: Global Education Database (GED), http://qesdb.cdie.org/ged/index.html.

Vaughan, M. K. (1975): «Education and Class in the Mexican Revolution». Latin American Perspectives, 2 (2), pp. 17-33. 
Wegenast, T. (2009a): «The Legacy of Landlords: Educational Distribution and Development in a Comparative Perspective». Zeitschrift für Vergleichende Politikwissenschaft, 3 (1), pp. 81-107.

- (2009b): Of Latifundia and Coronéis: Agrarian Structure and Educational Inequalities in Brazil. Working Paper prepared for presentation at the Mini-Conference "A Comparative Approach to Inequality and Development: Latin America and Europe», Madrid 8-9, May 2009.

Williamson, J.G. (1999): «Real Wages, Inequality and Globalization in Latin America before 1940». Revista de Historia Económica, 17, número especial, pp. 101-142.

- (2002): «Land, Labor and Globalization in the Third World 1870-1940». Journal of Economic History, vol. 62, No. 1, pp. 55-85.

World BANK (2004): Inequality in Latin America. Breaking with History? World Bank Latin American and Caribbean Studies, Washington: World Bank.

Yeager, G. M. (1991): «Elite Education in Nineteenth-Century Chile». The Hispanic American Historical Review, 71 (1), pp. 73-105. 


\section{APPENDIX}

FIGURE A.1

AVERAGE PER CAPITA DISPOSABLE INCOME ( $X$-AXIS) VERSUS AVERAGE DISPOSABLE INCOME OF TERTIARY EDUCATED (Y-AXIS) IN 2000 (1995 US \$)

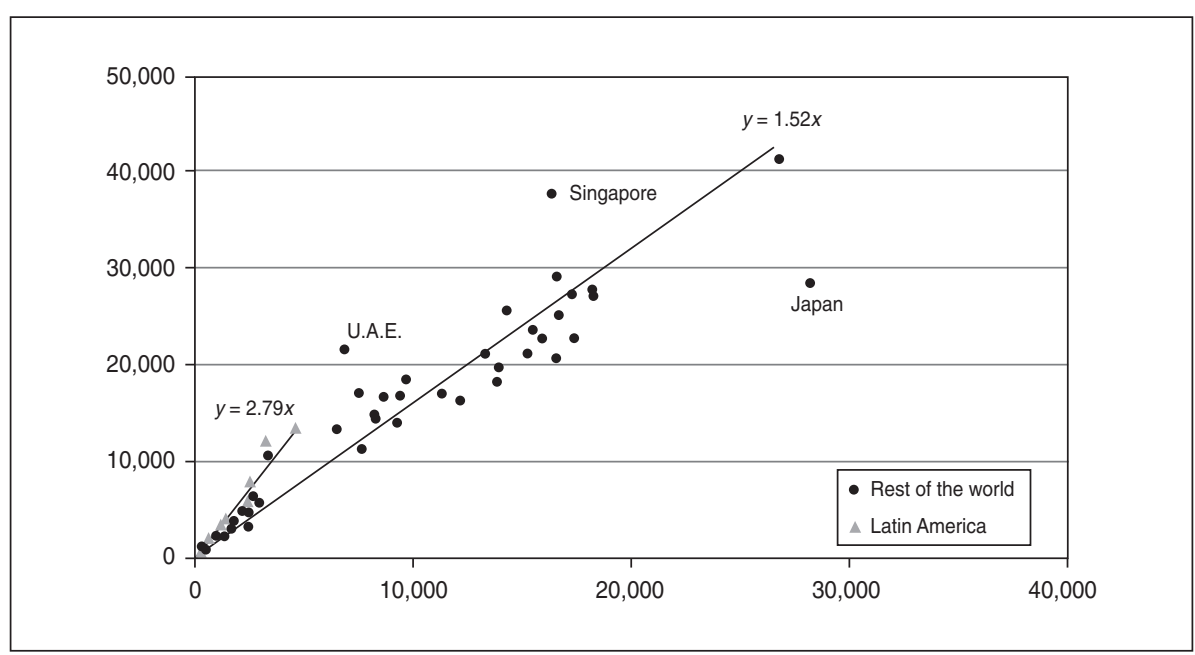

Sources: Euromonitor International (2007: pp. 102-107).

Notes: Latin American countries (9) included: Argentina, Bolivia, Brazil, Chile, Colombia, Ecuador, Mexico, Peru and Venezuela. Countries from rest of the world (62) included: Algeria, Australia, Austria, Azerbaijan, Belarus, Belgium, Bulgaria, Canada, China, Croatia, Czech rep., Denmark, Egypt, Estonia, Finland, France, Germany, Greece, Hong Kong, Hungary, India, Indonesia, Ireland, Israel, Italy, Japan, Jordan, Kazakhstan, Kuwait, Latvia, Lithuania, Malaysia, Morocco, Netherlands, New Zealand, Nigeria, Norway, Pakistan, Philippines, Poland, Portugal, Romania, Russia, Saudi Arabia, Singapore, Slovakia, Slovenia, South Africa, South Korea, Spain, Sweden, Switzerland, Taiwan, Thailand, Tunisia, Turkey, Turkmenistan, Ukraine, United Arab Emirates (U.A.E.), United Kingdom, United States, Vietnam.

TABLE A.1

AVERAGE ANNUAL INCREASE OF GROSS PRIMARY ENROLMENT RATE, LATIN AMERICA VERSUS A SELECTION OF NON LATIN AMERICAN COUNTRIES, 1830-2000

\begin{tabular}{|l|c|c|c|c|}
\hline & $\mathbf{1 8 7 0 - 2 0 0 0}$ & $\begin{array}{c}\text { Average annual } \\
\text { increase }\end{array}$ & $\begin{array}{c}\text { Three decades } \\
\text { of maximum } \\
\text { increase }\end{array}$ \\
\hline Argentina & $1880-1950$ & 1.1 & $1890-1920$ & 1.3 \\
\hline Bolivia & $1900-1990$ & 0.8 & $1930-1960$ & 1.4 \\
\hline Brazil & $1870-1980$ & 0.8 & $1920-1950$ & 1.2 \\
\hline Chile & $1880-1960$ & 1.1 & $1880-1910$ & 1.8 \\
\hline
\end{tabular}


TABLE A.1 (Continued)

\begin{tabular}{|c|c|c|c|c|}
\hline & $1870-2000$ & $\begin{array}{l}\text { Average annual } \\
\text { increase }\end{array}$ & & $\begin{array}{c}\text { Three decades } \\
\text { of maximum } \\
\text { increase }\end{array}$ \\
\hline Costa Rica & $1890-1960$ & 1.0 & $1890-1920$ & 1.1 \\
\hline Dominican Rep. & $1930-1960$ & 1.9 & $1930-1960$ & 1.9 \\
\hline Ecuador & $1920-1970$ & 1.2 & $1930-1960$ & 1.4 \\
\hline El Salvador & $1920-2000$ & 1.1 & $1930-1960$ & 1.8 \\
\hline Guatemala & $1920-2000$ & 0.8 & $1970-2000$ & 1.5 \\
\hline Honduras & $1930-1980$ & 1.4 & $1940-1970$ & 2.1 \\
\hline Jamaica & $1870-1960$ & 0.8 & $1870-1900$ & 1.2 \\
\hline Mexico & $1880-1970$ & 0.8 & $1920-1950$ & 1.3 \\
\hline Nicaragua & $1950-1980$ & 2.1 & $1950-1980$ & 2.1 \\
\hline Peru & $1900-1970$ & 1.3 & $1920-1950$ & 1.9 \\
\hline Trinidad \& Tobago & $1870-1960$ & 1.0 & $1870-1900$ & 1.4 \\
\hline Uruguay & $1900-1960$ & 1.3 & $1930-1960$ & 1.9 \\
\hline Venezuela & $1930-1960$ & 2.6 & $1930-1960$ & 2.6 \\
\hline \multicolumn{2}{|c|}{ Latin American average } & 1.25 & & 1.64 \\
\hline & $1830-1930$ & & & \\
\hline USA & $1830-1870$ & 0.6 & $1830-1870 *$ & 0.6 \\
\hline Austria & $1840-1920$ & 0.7 & $1870-1900$ & 0.8 \\
\hline Belgium & $1830-1920$ & 0.5 & $1890-1920$ & 1.1 \\
\hline France & $1830-1880$ & 0.9 & $1850-1880$ & 1.0 \\
\hline Spain & $1860-1930$ & 0.6 & $1900-1930$ & 0.8 \\
\hline UK (England-Wales) & $1830-1900$ & 0.7 & $1830-1860$ & 1.1 \\
\hline Japan & $1870-1910$ & 1.1 & $1870-1900$ & 1.1 \\
\hline \multicolumn{2}{|l|}{ Average } & 0.70 & & 0.92 \\
\hline & $1930-2000$ & & & \\
\hline Philippines & $1930-1960$ & 1.6 & $1930-1960$ & 1.6 \\
\hline Thailand & $1930-1980$ & 1.3 & $1930-1960$ & 1.5 \\
\hline Korea, rep. & $1930-1960$ & 2.6 & $1930-1960$ & 2.6 \\
\hline
\end{tabular}


TABLE A.1 (Continued)

\begin{tabular}{|l|c|c|c|c|}
\hline & $\mathbf{1 8 7 0 - 2 0 0 0}$ & $\begin{array}{c}\text { Average annual } \\
\text { increase }\end{array}$ & $\begin{array}{c}\text { Three decades } \\
\text { of maximum } \\
\text { increase }\end{array}$ \\
\hline Turkey & $1930-1960$ & 2.5 & $1930-1960$ & 2.5 \\
\hline Kenya & $1930-1980$ & 1.7 & $1950-1980$ & 2.5 \\
\hline Nigeria & $1930-1980$ & 1.9 & $1950-1980$ & 3.1 \\
\hline Malawi & $1970-2000$ & 3.3 & $1970-200$ & 3.3 \\
\hline Average & $\mathbf{2 . 1 2}$ & & $\mathbf{2 . 4 4}$ \\
\hline
\end{tabular}

Sources: Lindert (2004); UNESCO (1958); UNESCO, Statistical Yearbook, various issues 1966-1999. Notes: *USA average refers to four decades (1830-1870) due to lack of intermediate observations.

TABLE A.2

PERCENTAGE SHARES OF FEMALE IN PRIMARY, SECONDARY AND TERTIARY ENROLMENT, LATIN AMERICA VERSUS A SELECTION OF NON LATIN AMERICAN COUNTRIES, 1890-1997

\begin{tabular}{|l|c|c|l|l|l|l|l|l|}
\hline & \multicolumn{3}{|c|}{ primary } & \multicolumn{2}{c|}{ secondary } & \multicolumn{2}{c|}{ tertiary } \\
\hline & $\mathbf{1 8 9 0 / 1 9 0 2}$ & $\mathbf{1 9 5 0 / 5 4}$ & $\mathbf{1 9 9 0 / 9 7}$ & & $\mathbf{1 9 5 0 / 5 4}$ & $\mathbf{1 9 9 0 / 9 7}$ & $\mathbf{1 9 5 0 / 5 4}$ & $\mathbf{1 9 9 0 / 9 7}$ \\
\hline Argentina & 46.1 & 48.2 & 49 & & 30.7 & $52^{*}$ & 18.1 & 53 \\
\hline Brazil & & 49.1 & 48 & 44.1 & 52 & 22.4 & 52 \\
\hline Chile & 51.6 & 48.4 & 49 & 51.8 & 51 & 30.0 & 45 \\
\hline Colombia & & 49.0 & 50 & 39.2 & 54 & 12.5 & 50 \\
\hline Cuba & 46.8 & 50.6 & 49 & 43.4 & 53 & 40.3 & 57 \\
\hline Dominican Rep. & & 49.6 & 49 & 47.5 & 57 & & 57 \\
\hline Ecuador & & 45.2 & 49 & 29.7 & 50 & 15.4 & \\
\hline El Salvador & 43.3 & 49.0 & 49 & 39.8 & 55 & 10.9 & 48 \\
\hline Guatemala & 32.8 & 42.9 & 46 & 41.9 & 47 & & \\
\hline Jamaica & & 51.4 & 49 & 54.6 & 52 & 25.9 & \\
\hline Mexico & & 47.5 & 49 & 28.5 & 50 & 19.3 & 47 \\
\hline Panama & & 48.5 & 48 & 47.9 & 51 & 46.2 & 58 \\
\hline Paraguay & & 46.0 & 48 & 38.7 & 50 & 29.5 & 55 \\
\hline Peru & & 40.2 & 49 & 35.8 & 48 & 22.7 & $35^{*}$ \\
\hline Uruguay & 45.1 & 48.9 & 49 & 51.8 & 53 & & $53^{*}$ \\
\hline Venezuela & & 50.1 & 50 & 32.6 & 57 & 16.0 & 41 \\
\hline Latin America av. & $\mathbf{4 4 . 3}$ & $\mathbf{4 7 . 8}$ & $\mathbf{4 8 . 8}$ & $\mathbf{4 1 . 1}$ & $\mathbf{5 2 . 0}$ & $\mathbf{2 3 . 8}$ & $\mathbf{5 1 . 2}$ \\
\hline
\end{tabular}


TABLE A.2 (Continued)

\begin{tabular}{|c|c|c|c|c|c|c|c|}
\hline & \multicolumn{3}{|c|}{ primary } & \multicolumn{2}{|c|}{ secondary } & \multicolumn{2}{|c|}{ tertiary } \\
\hline & $1890 / 1902$ & $1950 / 54$ & $1990 / 97$ & $1950 / 54$ & 1990/97 & $1950 / 54$ & $1990 / 97$ \\
\hline \multicolumn{8}{|l|}{ Europe \& USA } \\
\hline USA & 48.5 & 48.4 & 49 & 51.3 & 49 & 30.1 & 54 \\
\hline France & 49.5 & 49.7 & 48 & 50.1 & 50 & 34.0 & 53 \\
\hline Netherlands & 48.0 & 48.7 & 50 & 42.3 & 47 & 15.4 & 44 \\
\hline Switzerland & 44.5 & 49.3 & 49 & 45.6 & 47 & 12.8 & 35 \\
\hline Spain & 42.9 & 50.4 & 48 & 35.2 & 51 & 10.4 & 51 \\
\hline Portugal & 31.9 & 45.0 & 48 & 46.6 & 51 & 24.9 & 56 \\
\hline Greece & 23.1 & 46.9 & 48 & 33.0 & 48 & & 48 \\
\hline Serbia/Yugoslavia & 14.3 & 46.0 & 49 & 43.0 & 49 & 32.2 & 53 \\
\hline \multicolumn{8}{|l|}{ Asia } \\
\hline Japan & 30.9 & 49.4 & 49 & 47.6 & 49 & 9.3 & 35 \\
\hline India & $9.3 * *$ & 29.1 & 41 & 14.5 & 37 & 4.9 & 33 \\
\hline China & & 39.0 & 46 & 31.9 & 41 & 9.1 & 33 \\
\hline Ceylon/Sri Lanka & 5.0 & 44.5 & 48 & 47.1 & 57 & 12.3 & 42 \\
\hline Burma/Myanmar & 7.8 & 45.0 & 48 & 47.8 & 49 & 22.7 & 55 \\
\hline \multicolumn{8}{|l|}{ Africa \& Mid. East } \\
\hline Turkey & & 37.1 & 47 & 25.0 & 37 & 19.6 & 34 \\
\hline Egypt & & 35.6 & 44 & 29.7 & 43 & 15.4 & 36 \\
\hline Ghana & & 25.4 & 45 & 11.5 & 44 & 7.1 & \\
\hline Uganda & & 25.7 & 40 & 15.0 & 39.0 & 12.9 & 27 \\
\hline Nigeria & & 22.0 & 43 & 8.5 & 42 & 4.3 & $29 *$ \\
\hline
\end{tabular}

Sources: Figures for primary enrolment 1890-1902 retrieved from Lindert (2004: p. 95); Figures for 1950-1954 from UNESCO (1958) and figures for 1990-1997 from USAID, Global Education Database (GED).

Notes: * Nigeria: figure refers to 1985; Argentina: figure refers to 1985; Peru: figure refers to 1980; Uruguay: figure refers to 1980; ** India 1900 is an unweighted average of Bombay, Punjab and Madras. 
TABLE A.3

CURRENT PUBLIC EXPENDITURE ON EDUCATION AS A PERCENTAGE SHARE OF GDP, LATIN AMERICA VERSUS A SELECTION OF NON LATIN AMERICAN COUNTRIES, 1954-1995

\begin{tabular}{|c|c|c|c|c|c|c|c|c|c|}
\hline & 1954 & 1960 & 1965 & 1970 & 1975 & 1980 & 1985 & 1990 & 1995 \\
\hline Argentina & 2.7 & 1.9 & 2.9 & 1.9 & 2.7 & 1.9 & 1.6 & 3.3 & 3.9 \\
\hline Bolivia & & 1.6 & 2.6 & 4.7 & 4.2 & 3.8 & 2.4 & 2.9 & 4.1 \\
\hline Brazil* & & 1.7 & 2.4 & 2.7 & 2.5 & & 2.7 & 3.7 & 4.5 \\
\hline Chile & 1.6 & 2.6 & 3.4 & 5.1 & 3.7 & 4.6 & 4.4 & $2.7 *$ & $3.0 *$ \\
\hline Colombia & 1.2 & 1.8 & 2.3 & 1.6 & 2.1 & 2.5 & 2.7 & 3.2 & 4.4 \\
\hline Costa Rica & 2.1 & 4.1 & 4.6 & 5.2 & 6.9 & 6.2 & 5.1 & 4.2 & 4.4 \\
\hline Dominican Rep. & & 1.4 & $2.7 *$ & 2.9 & $2.7 *$ & 2.1 & 1.5 & 1.1 & 1.8 \\
\hline Ecuador & 1.2 & 2.0 & 3.1 & 4.3 & 3.2 & 5.3 & 3.7 & 4.2 & $3.5 *$ \\
\hline El Salvador & & 2.3 & 2.8 & 2.8 & 3.3 & 3.4 & 2.7 & 1.9 & 2.1 \\
\hline Guatemala & & 1.4 & 2.0 & 2.0 & $1.7 *$ & 1.8 & 1.2 & 1.6 & 1.5 \\
\hline Haiti & & $1.6^{*}$ & 1.3 & 1.2 & 0.8 & 1.0 & 1.0 & 1.7 & \\
\hline Honduras & 1.0 & 2.2 & 2.9 & 3.1 & 3.9 & 3.0 & 4.7 & 4.2 & 3.6 \\
\hline Jamaica & & 2.5 & 3.3 & 3.5 & 5.9 & 7.5 & 5.3 & 5.4 & 6.4 \\
\hline Mexico* & 0.8 & 1.7 & 2.4 & 2.6 & 4.0 & 3.1 & 4.2 & 4.0 & 4.9 \\
\hline Nicaragua & & $1.6^{*}$ & 1.9 & 2.3 & 2.6 & 3.5 & 6.6 & 5.1 & 4.6 \\
\hline Panama & 3.6 & 3.6 & 4.1 & 5.4 & 4.9 & 4.5 & 4.9 & 4.1 & 4.1 \\
\hline Paraguay & & 1.3 & $1.9 *$ & 2.2 & 1.4 & 1.3 & 1.2 & 1.1 & 3.3 \\
\hline Peru & 0.9 & 2.7 & 5.1 & 3.8 & 3.9 & 2.5 & 3.0 & 2.5 & 2.3 \\
\hline Uruguay & & & 3.7 & 3.6 & & 1.9 & 1.6 & 1.9 & 3.2 \\
\hline Venezuela & 1.6 & 2.7 & 4.0 & 4.8 & 5.4 & 4.1 & 4.7 & 2.5 & 4.4 \\
\hline LA average & 1.7 & 2.1 & 3.0 & 3.3 & 3.5 & 3.2 & 3.2 & 3.0 & 3.7 \\
\hline Canada & $3.9 *$ & 5.8 & 6.3 & 8.6 & 7.0 & 7.1 & 6.1 & 6.3 & $6.5 *$ \\
\hline Netherlands & 4.6 & 5.9 & 6.3 & 7.8 & 6.8 & 7.6 & 6.4 & 6.0 & 5.2 \\
\hline Malaysia & & 4.1 & 4.9 & 5.5 & 5.4 & 6.0 & 6.6 & 5.5 & $5.2 *$ \\
\hline Philippines & 2.4 & 2.6 & 2.7 & 2.2 & 1.5 & 1.7 & 1.4 & 2.9 & 2.2 \\
\hline Thailand & 1.1 & 2.6 & 3.1 & 3.5 & 2.6 & 3.4 & 3.8 & 3.6 & 4.1 \\
\hline India & 2.0 & 2.3 & 2.6 & 2.6 & 2.8 & 3.0 & 3.5 & 3.9 & 3.4 \\
\hline
\end{tabular}

Sources: Expenditure figures for 1954 from UNESCO (1958); Other figures including both educational expenditure and GDP from UNESCO, Statistical Yearbooks, various issues 1966-1998 and UN, ECLAC/ CEPAL, Anuario Estadistico de America Latina, various issues 1964-2002.

Notes: Brazil: only central government budget; Canada 1956, 1994; Chile: excluding higher education in 1990 and 1995; Dominican Republic 1966: Ecuador 1997; Guatemala 1976; Haiti 1961; Malaysia 1996; Mexico: only central government budget; Nicaragua 1961; Paraguay 1966, 1973. 